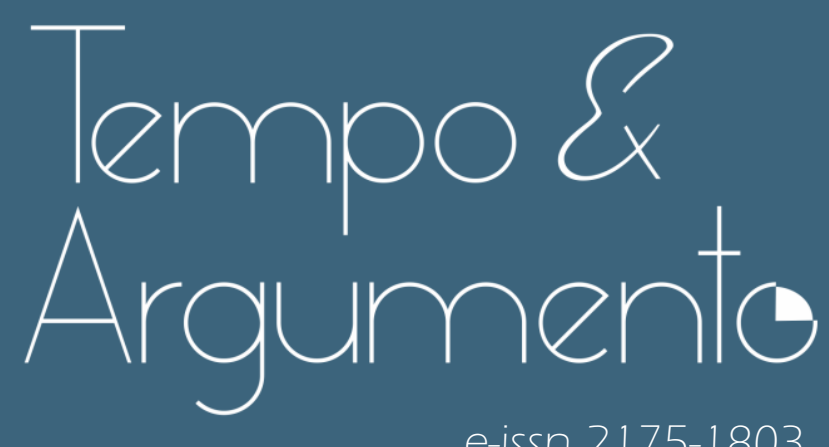

e-issn 2175-1803

\title{
Das massas e dos eleitores: povo, democracia e disputa política 1950-1960
}

• Luís Reznik

Doutor em Ciência Política pelo Instituto Universitário de Pesquisas do Rio de Janeiro (IUPERJ). Professor da Universidade do Estado do Rio de Janeiro (UERJ)

Rio de Janeiro, RJ - BRASIL

lattes.cnpq.br/9171209579621221

Iuisreznik@gmail.com

(iD)

orcid.org/0000-0002-5844-4777

- Mario Angelo Brandão de Oliveira Miranda

Doutor em Historia Social da Cultura pela Pontifícia Universidade Católica do Rio de Janeiro (PUC-Rio) e Doutor em História pela Pontificia Universidad Católica de Chile (PUC-Chile). Professor da Pontifícia Universidade Católica do Rio de Janeiro (PUC-Rio).

Rio de Janeiro, RJ - BRASIL

lattes.cnpq.br/2516783776536781

marioangelomiranda@gmail.com

(D) orcid.org/0000-0001-5125-1684

- Pablo de Oliveira de Mattos

Doutor em Historia Social da Cultura pela Pontifícia Universidade Católica do Rio de Janeiro (PUC-Rio). Estágio Pós-Doutoral na Université Libre de Bruxelles.

Bruxelas - BÉLGICA

lattes.cnpq.br/ 0480563172263434

pablodeoliveirademattos@gmail.com

(iD) orcid.org/0000-0001-8446-2525

Para citar este artigo:

REZNIK, Luís; MIRANDA, Mario Angelo Brandão de Oliveira; MATTOS, Pablo de Oliveira de. Das massas e dos eleitores: povo, democracia e disputa política 1950-1960.

Tempo e Argumento, Florianópolis, v. 13, n. 32, e0209, jan./abr. 2021.

doi

http://dx.doi.org/10.5965/2175180313322021e0209

Recebido: 13/03/2020

Aprovado: 04/02/2021 


\title{
Das massas e dos eleitores: povo, democracia e disputa política 1950-1960
}

\begin{abstract}
Resumo
Este artigo analisa as transformações nas linguagens políticas da década de 1950 no Brasil. Mais especificamente, os atos de fala relacionados à democracia e às avaliações feitas sobre a ampliação do voto, bem como em relação ao desenvolvimento econômico do país. Foram analisados editoriais de jornais de circulação nacional - Correio da Manhã, Tribuna da Imprensa, A Noite, Última Hora e Jornal do Brasil - durante as campanhas presidenciais de 1950, 1955 e de 1960. O pós-guerra no Brasil foi marcado pela perspectiva da mudança das estruturas nacionais. A percepção da necessidade de transformações sociais, econômicas e políticas esteve diretamente ligada a uma concepção de temporalidade própria desses "anos eufóricos". Esse cenário foi marcado pelo processo de democratização do Brasil e pela busca por desenvolvimento econômico. Os conceitos de democracia e desenvolvimento, neste sentido, serão disputados nas páginas dos jornais em meio ao intenso contexto político. A análise é feita a partir das contribuições da história dos conceitos e do contextualismo linguístico, entendidas neste artigo enquanto complementares do ponto de vista teórico e metodológico.
\end{abstract}

Palavras-chave: Linguagens políticas. Democracia. Desenvolvimento. Brasil PósGuerra. Povo.

\section{On the masses and voters: people, democracy and political dispute 1950-1960}

\begin{abstract}
This article analyzes the transformations in the political languages of the 1950s in Brazil. More specifically, the speech acts related to democracy and the evaluations made on the extension of the vote, as well as in the relation to the country's economic development. Editorials of national newspaper - Correio da Manhã, Tribuna da Imprensa, A Noite, Última Hora and Jornal do Brasil - were analyzed during the presidential campaigns of 1950, 1955 and 1960. The post-war period in Brazil was marked by the perspective of changing national structures. The perception of the need for social, economic and political changes was directly linked to a conception of temporality typical of these "euphoric years". This scenario was marked by the democratization process in Brazil and the search for economic development. The concepts of democracy and development, in this sense, will be disputes on the pages of newspaper in the midst of the intense political context. The analysis is made from the contributions of the history of concepts and linguistic contextualism, understood in this article as complementary from a theoretical and methodological point of view.
\end{abstract}

Keywords: Political languages. Democracy. Development. Post-war Brazil. People. 
A teoria de presente época no Brasil será irrecorrivelmente frustra, enquanto não refletir a consciência sistemática de um dado ordinário hoje na vida brasileira, porém que faltou nas épocas passadas. Esse dado é o povo. (RAMOS, 1961, p. 48)

Em meio ao debate em torno das eleições presidenciais de 1960 no Brasil, o Jornal do Brasil, publicou no dia 19 de agosto, editorial intitulado Democracia sem instrumentos. Nele, estava presente uma reflexão, até então, pouco difundida entre os grupos políticos nacionais:

a politização das massas... vem-se fazendo acima e além dos partidos políticos, e a única expressão positiva e decisiva desse aprendizado se concentra no exercício do voto, cada vez mais significativo no roteiro de nossa difícil evolução democrática. A consciência do voto é, hoje, em todas as regiões brasileiras, um fato de impressionante realidade política: ninguém se dispõe a abdicar de sua validade, ninguém aceita substitutivos a esta conquista. (DEMOCRACIA..., 1960, p. 3)

Segundo o JB, o povo brasileiro já havia manifestado interesse "consciente" pelas questões e problemas nacionais. E as tentativas de integração dos partidos na corrente popular eram, segundo o jornal, um sinal de confiança na sobrevivência do regime sem o sacrifício das liberdades. Dias mais tarde, a Tribuna da Imprensa, órgão que por duas vezes apoiou soluções extra-legais para crises políticas nacionais, argumentou, em editorial assinado por seu diretor e proprietário Carlos Lacerda, que "nesse período, grandes massas do povo amadureceram, despertaram, tomaram consciência da realidade nacional e dos caminhos que ela apresenta" (LACERDA, 1960, p. 3). Os editoriais apontam para a crença na capacidade de escolha política dos eleitores através do voto. Do ponto de vista conceitual, tal crença está ligada ao deslocamento do conjunto de eleitores considerados como massas em direção ao povo. Da mesma forma que

\footnotetext{
As discussões acerca da presença do povo na política atravessaram toda experiência democrática do pós-guerra. Contudo, o reconhecimento, nos meios políticos e acadêmicos, de seu papel consciente e decisivo no processo político, também evidenciado nos resultados eleitorais, se deu de forma gradual. Em 1961, Alberto Guerreiro Ramos (1961) alertava que a presença do povo na política era a novidade mais radical do Brasil de então. Para reforçar a dificuldade que os teóricos contemporâneos tinham em compreender essa "categoria histórica", o autor dialogou com trabalhos de Oliveira Viana (1949) e Gilberto Amado (1930), realizados em anos anteriores acerca das instituições políticas brasileiras, para analisar o "progresso do eleitorado brasileiro". Deixando para trás o paternalismo e a chamada "política de oligarquia”, o autor apresentava a política ideológica como a principal demanda do povo brasileiro de sua época. Ver também: RAMOS, Alberto Guerreiro. O problema nacional do Brasil. Rio de Janeiro: Saga, 1960.
} 
o trecho de Guerreiro Ramos aponta, esta era, portanto, uma conquista irrevogável em 1960.

Esses editoriais apresentam argumentos que marcam uma transformação nas linguagens políticas em torno do regime democrático no Brasil. Em 1960, se realizaria o quarto pleito presidencial desde o fim do Estado Novo. Esse primeiro período democrático de massas foi marcado pelo aumento significativo do contingente eleitoral com relação ao início do século e trouxe à tona um debate que atravessou toda a década anterior ${ }^{2}$. Dirigentes políticos, militantes e a imprensa, entre outros atores políticos, buscaram interpretar - e de certa forma controlar - o advento do novo conjunto de eleitores às urnas e entender seu comportamento no processo eleitoral e no jogo democrático.

Nas eleições presidenciais de 1950, em editorial publicado no dia 09 de outubro, o jornal $A$ Noite, em seu repúdio à vitória eleitoral de Getúlio Vargas, expressou uma concepção democrática de viés marcadamente elitista no qual a capacidade de escolha da população e a presença do que o jornal qualificou de massas no processo eleitoral foram duramente questionadas.

Não é sem grande dose de razão que numerosos dos mais profundos espíritos da cultura do ocidente rejeitaram a capacidade de seleção do povo, por vê-lo constantemente exposto aos equívocos da demagogia e da mistificação, para não falar na moderna técnica de mobilizar as massas. (O DRAMA..., 1950, p. 3)

Cinco anos mais tarde, durante a campanha eleitoral de 1955, embora alguns órgãos de imprensa já valorizassem a participação popular no pleito, a Tribuna da Imprensa, publicou: "Impõe-se agora, a vitória do povo sobre a massa. O povo é tiranizado pela ditadura das massas que, por via eleitoral, hoje, como ontem, pelo peleguismo e suas ramificações peronistas trata de se apoderar do poder para realizar seus intentos" (A NOVA..., 1955, p. 4).

\footnotetext{
2 Ao longo dos primeiros 55 anos republicanos, a participação política eleitoral no Brasil foi reduzida. Nas eleições de 1930, pleito cuja presença nas urnas foi bastante superior às eleições presidenciais anteriores, 1,9 milhão de eleitores, cerca de 5\% da população, compareceram às urnas. Nas eleições presidenciais de 1945, 6,2 milhões de eleitores votaram e em 1960, 12,5 milhões de eleitores participaram do pleito, alcançando 18\% da população (LAVAREDA, 1991; NICOLAU, 2002).
} 
Entretanto, comentários que colocavam em questão a capacidade do povo de exercer o voto de maneira consciente continuaram presentes nos debates políticos, em especial no discurso dos derrotados nos pleitos. Durante as eleições de 1960, a Tribuna da Imprensa, por exemplo, identificou os eleitores de Jânio Quadros como sendo o contingente mais politizado do povo brasileiro. Por outro lado, desqualificou a capacidade dos eleitores do marechal Henrique Lott em uma charge de autoria de Hilde Weber, publicada no dia 26 de agosto (Imagem 1).

Imagem 1 - Carro-chefe

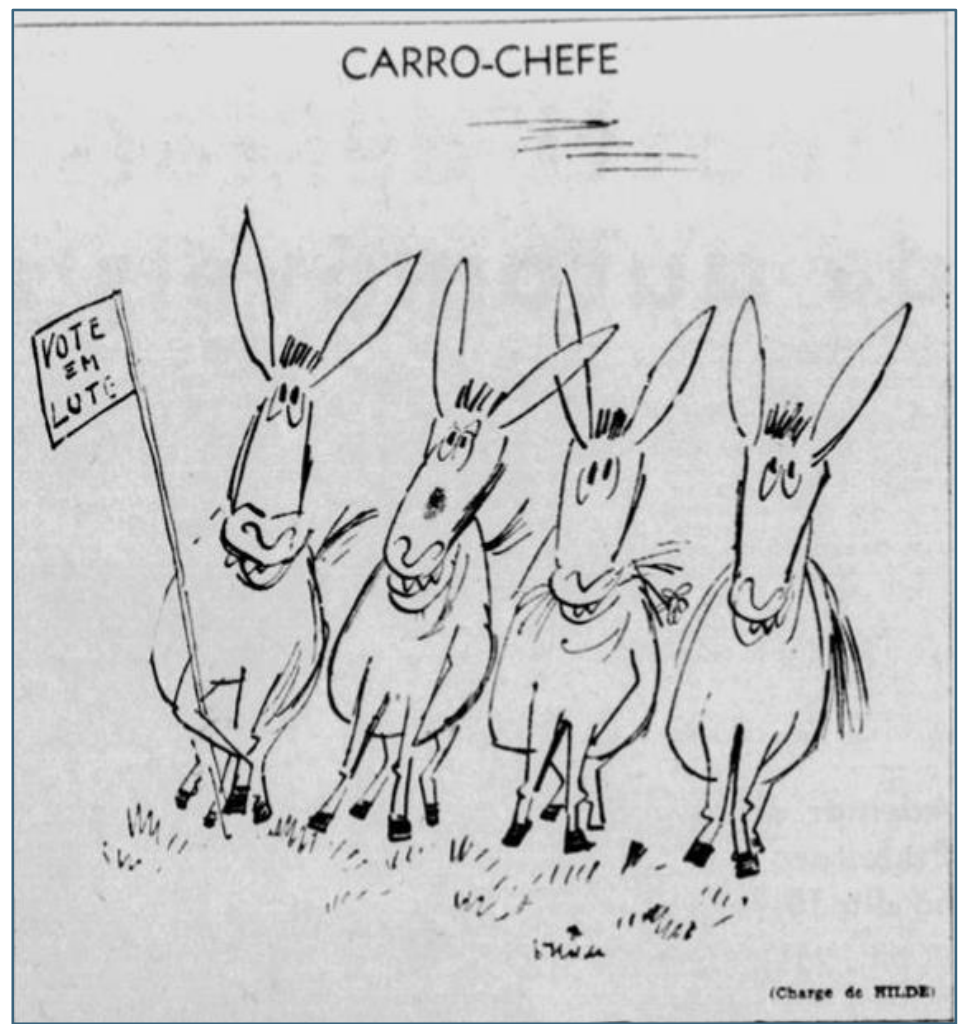

Fonte: WEBER, 1960, p.4.

Por uma história dos conceitos e dos atos de fala

O argumento central deste artigo é que o aumento do eleitorado no exercício democrático, somado a um conjunto de novas demandas sociais e políticas que tiveram lugar no Brasil dos anos 1950, trouxe impactos que possibilitaram variadas ressignificações de conceitos políticos. Essa transformação no vocabulário político foi marcada pela valorização da democracia liberal, baseada no voto da população (BENEVIDES, 1981; CHALOUB, 
2019). Os deslocamentos identificados em conceitos como os de povo e massa, portanto, - mas também os de democracia e desenvolvimento - representaram disputas de projetos nacionais e visões políticas do Brasil dos anos 1950.

O pós-guerra no Brasil caracterizou-se pela perspectiva da mudança das estruturas nacionais. A percepção da necessidade de transformações sociais, econômicas e políticas esteve diretamente ligada a uma concepção de temporalidade própria desses "anos eufóricos". Como bem aponta Celso Furtado (1985, p. 39), "estava na ordem do dia acreditar no Brasil e o momento estimulava a ousadia". Um novo tempo é diagnosticado e o momento presente é visto como dotado de uma dinâmica acelerada. O processo histórico do país é percebido por seus atores de maneira específica e as experiências do presente cada vez mais exerciam influência sobre a leitura do passado e sobre as expectativas do futuro. Ao Brasil cabia a missão de entrar o mais rápido possível no rol das grandes nações, abandonando assim, a condição de país dependente e subdesenvolvido. Para isso, deveria desenvolver-se economicamente e dar conta da consolidação da democracia, tão cara no contexto do Pós- II Guerra Mundial.

A criação do Estado Novo visou romper com a herança oligárquica da chamada "República Velha" e inaugurar um novo início político para o país. Com o fim do regime autoritário de Getúlio Vargas, o debate político da década de 1950 traduziu essa experiência como uma transição a ser direcionada e dirigida. Frente aos distintos projetos e expectativas de democratização e desenvolvimento nacional, a memória da experiência varguista no Estado Novo foi controlada e submetida a diversas interpretações.

O alargamento dos direitos sociais no primeiro governo de Vargas trouxe à política um corpo de atores sociais que até então se encontrava alijado de decisões ou participação no processo político formal. A democratização da política brasileira, imaginada em 1942 e posta em marcha em 1945, impulsionou a discussão sobre a inclusão e participação política desse novo contingente eleitoral (BETHELL, 1996; GOMES, 1988). Em 1950, a campanha de Getúlio Vargas foi marcada pelo diálogo direto e atento às demandas das classes populares. Seus opositores, por sua vez, atacavam o diálogo com o que consideravam serem as massas, qualificando-o de demagógico (FERREIRA, 2001, p. 111-113). 
Outro aspecto que exerceu influência no debate político da década de 1950 foi a reflexão acerca do desenvolvimento econômico. Com o declínio da preponderância da agroexportação cafeeira e a intensificação da industrialização buscou-se um projeto modernizador que proporcionasse a entrada do Brasil na categoria de nação desenvolvida e independente, o que se entendia à época como soberania nacional (BENEVIDES, 1991; BIELSCHOWSKY, 1988; FURTADO, 1985; GOMES, 1991; GUIMARÃES, 2001). O futuro desejado não guardava semelhanças com algo antes vivido pelo país. No plano linguístico, as expectativas foram enfeixadas de maneira que, na linguagem - em suas diversas expressões -, ocorresse um processo de transformação e inovação. A novidade das experiências vividas no presente conferiu às expectativas de futuro qualidades inesperadas. Passado, presente e futuro relacionavam-se de maneira particular na linguagem.

Este artigo se fundamenta nas contribuições de duas escolas de análise histórica que consideram as linguagens como campo privilegiado de estudo. Entretanto, as duas correntes compreendem que a História não pode ser interpretada apenas por meio da linguagem. Dito de outro modo, a História deve ser entendida em seu domínio próprio, não redutível à linguística ou à sua análise estrita. "Linguagem e história permanecem dependentes uma da outra, mas nunca chegam a coincidir inteiramente" (KOSELLECK, 2006, p. 267). A história dos conceitos, é aqui trazida através das obras de Reinhart Koselleck, e do contextualismo linguístico (ou Escola de Cambridge) nas obras de Quentin Skinner e J.G.A. Pocock.

Ambas as escolas representam tentativas de superação dos modelos tradicionais da história das ideias dentro de um debate que remonta à década de 1960. Entretanto, há aqueles que salientam, de forma mais ou menos crítica, a polarização das interpretações caracterizada por, de um lado, uma análise textual e, de outro, uma análise contextual (BOTELHO; SCHWARCZ, 2011). O que se apresenta neste artigo, contudo, é a possibilidade de associação entre tais correntes a partir de suas possibilidades teórico-metodológicas comuns: a análise da linguagem enquanto indicador histórico, mas também como fator da 
história e, tendo em vista seu caráter histórico, as interações e transformações conceituais e linguísticas percebidas tanto na sincronia quanto na diacronia.

Algumas conclusões de Reinhart Koselleck consideram que as transformações conceituais foram constituídas - e se constituem ao longo do tempo - pelas experiências vividas e pelas expectativas das pessoas nelas inseridas (KOSELLECK, 2006, p. 306). É a interação entre as categorias metahistóricas de espaço de experiências e horizonte de expectativas que possibilita a dinâmica histórica. As propostas de Pocock (2003), por sua vez, buscam dar conta de análises que considerem mais as linguagens políticas e seus contextos (langue), e menos os atos de fala (parole) produzidos nas linguagens. A linguagem política surge, portanto, enquanto categoria que compreende o fenômeno de retórica e do discurso, e é entendida como forma reiterada de se constituir e comunicar valores e ideias diante da interação - ou jogo - (performance) dos atores de uma comunidade linguística. Para Pocock, a linguagem se torna visível na medida em que se institucionaliza como forma de discurso, ou seja, quanto mais suas ideias e formas de expressão se tornam convencionais em atos de fala. Já Quentin Skinner, aponta para a importância de se analisar genealogias das ideias políticas (SKINNER, 2001, 2002) articulando sincronia e diacronia, dimensões incontornáveis, e mesmo indissociáveis, no estudo do pensamento político. ${ }^{3}$ Nesse sentido, este artigo mapeou, ao longo dos debates eleitorais da década de 1950, as disputas em torno de alguns conceitos e a formação de linguagens políticas comprometidas com os rumos da democracia no Brasil.

As contribuições do historiador alemão Reinhart Koselleck sobre as transformações na linguagem da Europa, especialmente entre a segunda metade do século XVIII e a primeira do XIX, estão organizadas em várias obras, especialmente em seu livro Futuro Passado: Contribuição à semântica dos tempos históricos. ${ }^{4} \mathrm{O}$ autor elaborou um diagnóstico acerca das transformações

\footnotetext{
${ }^{3}$ A obra de Quentin Skinner, As fundações do pensamento político moderno (2006), pode ser tomada como modelo de abordagem que articula sincronia e diacronia. Ao buscar compreender as fundações e a formação da moderna concepção de Estado ao longo de três séculos de história, o autor procura, na compreensão dos diversos vetores, identificar as continuidades e rupturas do legado da tradição escolástica e dos glosadores.

${ }^{4}$ Ver também: KOSELLECK, Reinhart. historia/Historia. Madrid: Trotta, 2004; KOSELLECK, Reinhart. The pratice of conceptual history. timing history, spacing concepts. Stanford: Stanford University Press, 2002;
} 
nas maneiras de se perceber e nomear fenômenos históricos como parte de um processo amplo de modernização e percepção específica do tempo. Essas mudanças radicais na linguagem são o objeto da história dos conceitos. Além da ressignificação de conceitos políticos em consonância com o novo tempo, a criação de novos conceitos dotados de uma temporalidade específica são aspectos teóricos que norteiam o trabalho da história dos conceitos.

Para Koselleck (2006), o processo de formação de conceitos teria algo a dizer sobre mudanças históricas. A diferença primordial entre a palavra e o conceito seria a existência ou não de uma disputa profunda e central por seu significado. Atores políticos da década de 1950 brasileira ressignificaram conceitos, dotando-os de possibilidades políticas inovadoras a partir de intensas disputas nas páginas dos jornais de grande circulação. Diante da morte de Getúlio Vargas e da disputa por seu eleitorado - e seu legado político -, os conceitos de povo e massa, por exemplo, representaram mais do que formas linguísticas de nomear e qualificar a população que entrava no jogo eleitoral. O povo passa a ser visto - e disputado - enquanto eleitorado consciente e apto ao exercício do voto.

A presença das massas, por sua vez, qualificaria antitética e assimetricamente o jogo eleitoral e democrático. Tais conceitos serão teorizados de forma que indiquem afiliações, projetos, níveis de consciência e racionalidade política, mas também formas de imaginar os rumos da democracia. O conceito de desenvolvimento, por sua vez, nos aponta para as formas pelas quais intelectuais e atores políticos percebiam o momento como um período de transição. Tal qual Koselleck propõe (2006, p. 284), além do critério da transição, a anacronia também é revelada pelo conceito de desenvolvimento.

A temporalização identificada na modernidade por Koselleck auxilia nas análises do vocabulário político brasileiro do pós-Guerra. A percepção do presente enquanto possuidor de um tempo próprio carregado de sentido, tomado por seus atores como um período de transição é um desses critérios. Ao

KOSELLECK, Reinhart. Los estratos del tiempo: estudios sobre la historia. México: Paidós Ibérica, 2001; KOSELLECK, Reinhart. Histoire sociale et histoire des concepts. In: L'EXPERIENCE DE L'HISTOIRE. COL. HAUTES ÉTUDES. Paris. Gallimard/Seuil, 1997; KOSELLECK, Reinhart; GADAMER, Hans-Georg. Historia y hermenéutica. Barcelona: Paidós, 1997 e; JASMIN, Marcelo Gantus; FERES JUNIOR, João. Uma história dos conceitos: debates e perspectivas. Rio de Janeiro: PUC-RIO: Edições Loyola: IUPERJ, 2006. 
longo dos debates eleitorais da década de 1950, os conceitos de povo e massa, por exemplo, traduziram projetos comprometidos - de maneira mais "substantiva" ou apenas parcial - com a ampliação ou a consolidação da democracia. O período também foi marcado pela intensa busca da modernização das estruturas econômicas registrada nas disputas em torno do conceito de desenvolvimento. Outro critério que nos importa é o da anacronia, ou seja, a simultaneidade do não simultâneo.

Nesse período, a leitura do jogo democrático foi atravessada pela percepção de que havia alguns homens - e mulheres - importantes e mais esclarecidos do que outros, coexistindo no jogo político. O conceito de democracia e seus correlatos indicam que o suposto atraso das massas não esclarecidas deveria ser tratado pela educação e pelo exercício do voto, ou até mesmo por sua interdição ao jogo eleitoral. Haja vista que alguns idiomas políticos consideravam que o "despreparo" das massas seria um signo da corrupção do regime. Diante desse esquema, é possível compreender projetos a partir de seus mecanismos e critérios temporais, colocados sob a alternativa de progredir ou conservar, recuperar o tempo ou torná-lo mais lento. A qualidade temporal do período, tal qual na modernidade analisada por Koselleck, permite aos atores políticos a utilização do tempo como ferramenta de ação política. Nesse sentido, os conceitos de povo e massa assumem centralidade neste artigo, pois permitem que os critérios e a qualidade temporal do processo político brasileiro da década de 1950 sejam identificados através de sua interpretação.

Os conceitos de movimento, ao extraírem do presente os aspectos positivos, orientam-se para o futuro desejado de maneira que a direção política a ser tomada seja indicada por seu conteúdo. O caráter subjetivo da história e a polissemia dos conceitos mobilizados, portanto, acirram as disputas pela leitura do passado e pelos projetos de futuro. O conceito de desenvolvimento, por exemplo, apresentará além das inflexões dos nacionalistas, aquelas mais comprometidas com os setores privado ou público ou, ainda, com o liberalismo. Além disto, a ênfase dada ao setor industrial ou agrário ou mesmo ao papel de trabalhadores e da sociedade na definição dos rumos - e da liderança desse processo - do desenvolvimento indicam projetos políticos e arranjos temporais 
distintos. Outro aspecto importante desses conceitos é sua característica legitimadora dos rumos e projetos a serem seguidos, pois, por cotejarem experiências parcialmente vividas, o futuro desconhecido está em proporção inversa à experiência que lhes falta. São conceitos de compensação temporal, se apresentam como gênese do futuro. Futuro, este, que depende da ação política - das massas ou do povo - frente à situação existente e ao diagnóstico crítico do passado histórico.

Ao analisar as ações políticas no campo da linguagem, é necessário verificar a sua apreensão dentro do contexto em que foi produzida, bem como a carga semântica que o conceito carrega através do tempo. A percepção do texto inserido em seu contexto atua na reconstrução de sua identidade histórica, ao mesmo tempo em que lhe atribui o caráter de ação, isto é, o texto entendido como ato de fala (POCOCK, 2003, p. 55). Nesse sentido, a abordagem se baseia na especificidade do discurso em diálogo com outros atos de fala, e não apenas em uma coerência autoral individual e isolada do ator/autor. Por essa trilha, podemos afirmar que a análise do historiador deve priorizar as "linguagens do discurso".

Por um lado, isso significa que, a partir da influência de R. G. Collingwood, o contextualismo linguístico recupera a ideia de que as obras do pensamento devem ser compreendidas como formas de intervenção em um dado contexto intelectual ${ }^{5}$. Ou seja, a tarefa de compreender o que um texto diz - seria a de entender as obras como tentativas de formular respostas para questões postas a seu tempo. A análise do contexto, contudo, é o que fornecerá as perguntas. É a partir da interação sincrônica entre os atores políticos que se percebe quais problemas orientam a ação desses indivíduos

Por outro lado, Pocock, sem se afastar de Skinner, ressalta outro aspecto na tentativa de diferenciar a abordagem da história do pensamento político e a perspectiva da filosofia política. Sugere que, como marca do pensamento abstrato, haja a preocupação com a coerência teórico-conceitual. E que a

\footnotetext{
5 As reflexões propostas pelo filósofo inglês são de tal forma significativas para os autores que se filiam a esaa perspectiva historiográfica, que o próprio Skinner, seu principal expoente, viria a rebatizá-la de enfoque ou abordagem collingwoodiana (JASMIN; FERES JUNIOR, 2006, p. 11).
} 
identidade da filosofia deveria ser, portanto, encontrada também enquanto formadora de uma tradição histórica específica (POCOCK, 2009). Ou seja, abre espaço para que se considere a carga semântica construída sobre determinado debate ou conceito através do tempo, diante de diversos contextos. Para Pocock, uma comunidade argumentativa, ou a partilha de uma mesma problemática, indicaria a formação de uma tradição filosófica e retórica (atores/intelectuais debatendo com outros atores/intelectuais, utilizando termos e conceitos formados ao longo do tempo) que teria continuidade ao longo do tempo, e que não seria redutível à análise filosófica. Pocock ressalta que o ditado 'história é política do passado" deve ser compreendido mais a fundo pois, "a história da historiografia é, em tão grande medida, parte da história do discurso político" (POCOCK, 2003, p. 128).

Existiria, assim, um deslocamento no que se refere às preocupações de um filósofo e de um historiador da filosofia. Portanto, ao analisar conceitos e o vocabulário político da década de 1950 no Brasil, mobilizados durante campanhas eleitorais, foi possível identificar conceitos e atos de fala que correspondiam a questões prementes e sincrônicas. Por outro lado, também pode-se produzir uma compreensão diacrônica das transformações e continuidades conceituais nas linguagens políticas, levando em consideração tradições políticas e teóricas extemporâneas e um debate vinculado a um ambiente político regional ou mesmo global, como aquele articulado ao contexto da Guerra Fria, por exemplo.

Não obstante, essa forma de análise permite ampliar o debate historiográfico sobre o período ao se distinguir linguagem e história. No que se refere ao debate sobre o conceito de populismo, por exemplo, foi possível perceber nas páginas dos jornais o caráter secundariamente avaliativo do conceito diante das questões eleitorais e sua extrema politização. A possibilidade de reconstituição de uma comunidade argumentativa ou de discurso é o que assegura o caráter de fenômeno histórico. Através da análise dos contextos intelectual, político e econômico que informam os atos de fala durante a década de 1950, torna-se possível perceber alguns dos significados atribuídos aos conceitos de democracia e desenvolvimento, bem como a ideia de Nação desejada - e disputada - por esses grupos. 
Os indivíduos envolvidos nesta batalha semântica em direção ao 'progresso' da nação contribuíram para a criação de uma determinada "comunidade argumentativa" composta por vários idiomas, elaborando e emitindo "lances" específicos, ou seja, promovendo a interação entre contexto e texto - langue e parole?. Essa interação produz contextos linguísticos que determinavam o que seria dito, e, ao mesmo, tempo sofriam a ação daquilo que era dito. Quanto mais complexo/contraditório é o contexto linguístico em que se situam, mais ricos e ambivalentes serão os conceitos e atos de fala e maior será a probabilidade de que esses atos de fala atuem sobre o próprio contexto, modificando-o.

No debate, o papel exercido pela imprensa foi de grande relevância, constituindo-se em um ator político social que, para além de mediador da opinião pública, pode ser entendido como a expressão da opinião compartilhada por grupos políticos variados. Nos anos 50 e 60 havia uma grande variedade de jornais com expressiva circulação. As inúmeras inovações tecnológicas ocorridas no período se associaram a um processo de transformação na linguagem no qual os órgãos de imprensa buscavam se aproximar do grande público ${ }^{8}$. A influência da televisão ainda era reduzida e os jornais se apresentavam como importante

\footnotetext{
6 Apropriada da reflexão de John Pocock (2003, p. 69) sobre a noção de comunidade argumentativa não remete à ideia de entrelaçamento de distintas linguagens isoladas, mas de um conjunto único, que incorpora a multiplicidade de "sub-linguagens" ou idiomas.

7 Segundo Pocock (2003, p. 66), "o historiador deve mover-se da langue para a parole, do aprender a linguagem para determinar os atos de enunciação que foram efetuados ‘dentro’ dela”. A noção de idiomas políticos remete à ideia de discurso e se relaciona com as maneiras de pensar e falar a política, pelos mais variados grupos em meio ao debate.

8 Tal como aponta Ana Paula Ribeiro (2003), ao longo dos anos 50, o jornalismo brasileiro vivenciou um conjunto de reformas que dialogava com uma gradual substituição de seu viés políticoliterário por uma perspectiva empresarial. Na esteira dessas mudanças, é possível perceber que os jornais promovem uma série de ações vinculadas à construção de uma identidade própria, padronização dos textos e adoção de um novo design e formatos de apresentação das notícias, que faziam parte de uma estratégia comercial, de mercado. Ou seja, ampliar o público leitor, estimular o consumo e facilitar a incorporação de propaganda. Da mesma forma, a valorização da objetividade, da impessoalidade e o gradual processo de profissionalização dos jornalistas desembocou na formação de uma comunidade discursiva própria, com capital simbólico reconhecido e fala autorizada, transformando o campo jornalístico em um ator social reconhecido. Por outro lado, autora destaca que os aspectos políticos jamais desapareceram. As relações com grupos políticos que, dentre outras coisas, garantiam acesso a financiamentos, créditos e mesmo publicidades, eram na verdade aspectos estruturantes e mesmo garantidores da sobrevivência de muitos jornais. Talvez indo um pouco mais além, entendemos que os discursos e linguagens expressos na grande imprensa também dialogam com as demandas de seus leitores e, em última análise, com os esforços de proposição e a necessidade de adaptação também às transformações sociais e aos projetos então em disputa.
} 
fonte de orientação política para diversos setores da sociedade civil brasileira. Entre os cidadãos, se percebia um forte processo seletivo na escolha dos jornais, consolidando seus vínculos político-partidários. Ao mencionar o resultado de pesquisa realizada em agosto de 1950, que questionava os eleitores sobre o tipo de mídia em que eles se orientavam sobre a política, Antônio Lavareda (1991, p. 128-129) comenta que 66\% deles viam nos jornais sua principal fonte.

A imprensa caracterizava-se como espaço dinâmico privilegiado de politização e conexão com as campanhas eleitorais. Ao assumir posições partidárias claras em algumas eleições, ou manter consistentes ligações com partidos políticos e parlamentares, os jornais traziam, em suas seções de opinião ou nas transcrições dos discursos dos candidatos, as significações que possibilitavam a ideologização mútua dos adversários políticos na "batalha semântica”.

Nesse sentido, com o objetivo de captar as transformações, alterações de significados e diferentes usos dos conceitos de democracia e desenvolvimento, assim como a ideia de nação ideal, no contexto político dos anos 1950, procuramos analisar os editoriais de diferentes jornais da cidade do Rio de Janeiro 9 . Os debates em torno dos pleitos eleitorais presidenciais de 1950, 1955 e 1960 foram escolhidos como recorte em virtude do acirramento das discussões e da efervescência dos debates políticos em períodos de campanha eleitoral. Dessa maneira, a pesquisa identificou diversos idiomas políticos que se relacionaram ao longo da década, bem como as transformações do vocabulário político mobilizado.

A seleção dos jornais, obrigatoriamente diários, se deu em função de sua representatividade, ou da especificidade de suas posições no debate político. Principal matutino da cidade, o Correio da Manhã foi analisado nas três

\footnotetext{
${ }^{9}$ Os idiomas expostos na grande imprensa, certamente, não são capazes de incorporar em toda sua profundidade, os discursos dos mais distintos atores presentes na sociedade brasileira. Contudo, em virtude da referida diversidade de opiniões, é possível se verificar na grande imprensa os discursos de maior repercussão e mapear as muitas outras vozes que se manifestavam no cenário político nacional. Ao entender os editoriais da imprensa como atos de fala que compõem os idiomas, ou as maneiras de pensar e falar a política em meio à batalha semântica em torno dos conceitos analisados, procura-se justamente reconstituir, a comunidade argumentativa do período (POCOCK, 2003, p. 63-83).
} 
campanhas selecionadas. Embora afirmasse sua independência partidária, o Correio da Manhã, que se intitulava um "jornal de opinião", adotava uma postura liberal e moderada ${ }^{10}$. Também presente nos três momentos analisados, a Tribuna da Imprensa, vespertino fundado pelo jornalista Carlos Lacerda em 27 de dezembro de 1949, pode ser considerado como a expressão de setores udenistas mais radicais, "a chamada Banda de Música", ou do próprio Lacerda. Apresentando-se como um órgão liberal, cristão e defensor da livre iniciativa, o jornal notabilizou-se por sua contumaz oposição às propostas classificadas como varguistas ao longo de todo o período. Como contraponto, procurou-se analisar as posições de Última Hora, único jornal de grande circulação que manteve uma linha editorial de apoio a Vargas durante todo seu governo e que, após a sua morte, continuou declarando-se herdeiro e fiel seguidor de seus ideais. Fundado em 1951, pelo jornalista Samuel Wainer, com o apadrinhamento político do presidente Getúlio Vargas, o jornal foi analisado nas campanhas de 1955 e $1960^{11}$.

Durante o pleito de 1950, nenhum órgão da grande imprensa se posicionou favoravelmente a candidatura Vargas. Contudo, para se ampliar o espectro de investigação nesse momento, optou-se pela análise dos editoriais de A Noite. Em

\footnotetext{
${ }^{10} \mathrm{Em}$ meio às transformações vivenciadas no jornalismo brasileiro, o Correio da Manhã manteve seu formato de apresentação, com reportagens ocupando distintas páginas e sua tradicional primeira página destinada a temas internacionais. O debate econômico era tema de colunas e editoriais diários que afirmavam sua postura liberal, favorável à abertura ao capital estrangeiro como caminho para o desenvolvimento nacional. O debate político ocupava significativo espaço interno e seus editoriais e colunistas apresentavam o jornal como defensor da "legalidade democrática", da constituição e das liberdades (ABREU et al., 2001, p. 1628-1631; BARBOSA, 2007; LATTMAN-WELTMAN, 1996; MIRANDA, 2014, p. 40).

11 Desde sua fundação, Última Hora teve como foco a ampliação do público leitor. Adotando novos designs e padrões de diagramação, com fotos objetivas, charges e com o uso da primeira página como "vitrine", em menos de seis meses se transformou no vespertino de maior circulação do Distrito Federal. Para atingir as camadas populares e ampliar seu público leitor, Ultima Hora fez uso de uma linguagem mais objetiva, informal e inovou com sua programação esportiva e com um noticiário específico sobre os bairros. Tendo a política como tema central, o jornal sustentava uma postura nacionalista e de defesa permanente da legislação trabalhista e seu legado, protagonizando ainda, intensas polêmicas políticas e mesmo pessoais com a Tribuna de Imprensa e seu fundador - cujo jornal procurava atingir o mesmo público, adotando uma postura marcadamente anticomunista e crítica daquilo que nomeava como herança ditatorial varguista. Anunciadas sempre em primeira página, as colunas de Lacerda e os encontros do Clube da Lanterna, associação que reunia parlamentares udenistas e simpatizantes, o jornal manteve uma linha editorial basicamente voltada para a política local e nacional. Contudo, também incorporou as novas tendências gráficas e lançou cadernos especiais voltados para temas cotidianos e, especificamente, para mulheres (ABREU et al., 2001, p. 5790-5792; p. 58295832; LATTMAN-WELTMAN, 1996; MIRANDA, 2014, p. 41; RIBEIRO, 2003, p. 151-158; SODRÉ, 1999, p. 394-410).
} 
1946, um decreto presidencial autorizara o arrendamento do jornal, então em grave crise econômica e administrativa, a uma sociedade anônima constituída por antigos funcionários. No pleito de 1950, esse fato, somado a constante veiculação de realizações do governo Dutra, transformou $A$ Noite em alvo prioritário de inúmeros ataques da Tribuna da Imprensa e de seu proprietário (ABREU et al., 2001, p. 4107)12. A base documental de pesquisa se complementa com a inclusão, no pleito de 1960, dos editoriais do Jornal do Brasil. A escolha se justifica em função de uma série de transformações e investimentos, ocorridos durante os anos 1950, que, aos poucos, recolocaram o jornal em uma posição de destaque na linha opinativa. Ainda assim, o JB não abandonaria a sua tradicional moderação política, e sua condição de órgão apartidário, católico, constitucional e defensor da iniciativa privada (ABREU et al., 1996, p. 154).

\section{Os limites da democracia e os distintos caminhos do desenvolvimento}

Nas eleições presidenciais de 1950, o Correio da Manhã procurou afirmarse como legalista e defensor das liberdades democráticas, manifestando apoio à candidatura do udenista Eduardo Gomes. Seu editor-chefe, Luís Costa Rego, deputado pela União Democrática Nacional (UDN), publicou reiteradamente que a candidatura do brigadeiro Eduardo Gomes representava uma nova época para o Brasil, ao trazer dignidade política, prosperidade nacional, além de afastar os horrores do passado e do presente. Getúlio Vargas representava o retorno ao passado, "uma época de desordem sob a aparência de uma rígida ordem fascista” (UM MÊS, 1950, p. 1). Já Cristiano Machado, candidato pelo Partido Social Democrático (PSD), representava apenas a continuação do "atual estado de coisas". Ao mencionar em editorial os problemas no processo da "restauração" democrática de 1945, o Correio da Manhã publicou que:

\footnotetext{
12 Em função do agravamento de seus problemas administrativos e de circulação ao longo do governo de Vargas (1951-1954), que culminaram em seu fechamento em 1957, optou-se por não se realizar a análise deste jornal em 1955.
} 
o voto do eleitor é em nossa escassa democracia, alguma coisa que as forças políticas responsáveis ainda não perderam o vezo em considerar em termos de artifícios, como se as instituições livres pudessem vicejar e sobreviver na negação de si mesmas, através de uma política dirigida coercitivamente pelo temor do estado e pela corrupção do dinheiro. Dos muitos erros da restauração democrática de 1945, o mais doloroso, foi a especulação do pleito na omissão da consciência dos votantes. (IDENTIDADE..., 1950, p. 1)

Em 1950, grupos liberais preocupavam-se com um novo ator político, as camadas populares que apoiavam Getúlio vargas. A presumida falta de consciência e racionalidade política dessa parcela, impunha-lhes um problema: como será ouvido e acreditado o discurso democrático de Getúlio Vargas? "O problema não é dele nem nosso. É um problema da consciência, memória e sensibilidade para o povo brasileiro" (O QUE..., 1950, p. 1). Esses grupos acreditavam que a emancipação política do povo brasileiro seria alcançada somente sob um regime democrático dirigido por uma elite consciente. Não é de menor importância a identificação de uma "restauração". O fim do Estado Novo "restaurava" a democracia, ou nos termos da época, "redemocratizava" a política nacional. Nesses termos, para o Correio da Manhã, encampando a campanha udenista e bacharelesca, democracia era praticamente sinônimo de regime liberal, tal qual o ambiente político pré-1930. Entretanto, os editores apontavam a notícia dos novos tempos, em que era imperioso doutrinar o novo eleitorado:

A um tempo de doutrinação democrática e de convocação do eleitorado para a decisão política de outubro, esta campanha visa dar ao povo a consciência de si mesmo e de sua influência inelutável na prática e no aperfeiçoamento das instituições vigentes. Numa palavra: é uma campanha de participação popular... Formar um eleitorado consciente não apenas pela capacidade de escolher bem, mas pela confiança nas soluções do sufrágio direto e secreto, é missão precípua na organização do regime, vinculando-o sinceramente ao funcionamento da vontade popular. (PLANO..., 1950, p. 1)

A maior parcela do eleitorado de 1945 votava pela primeira vez para presidente. De 1930 a 1945, a variação no número de eleitores aptos a votar no Brasil foi impressionante. O alistamento obrigatório realizado após a chamada “Lei Agamenon”, decreto-lei que regulamentava o pleito de 1945, registrou 6,168 milhões de eleitores, o que representava um crescimento de 329\% com relação 
ao último alistamento, realizado em 1933, após a promulgação do Código Eleitoral de 1932 (NICOLAU, 2002, p. 43). Esse crescimento se deve a um conjunto de fatores. A Constituição de 1934 reduziu a idade eleitoral de 21 para 18 anos e instituiu a obrigatoriedade de alistamento e voto para homens e funcionárias públicas. Contudo, diante da proximidade das eleições daquele ano, a medida surtiu pouco efeito sobre o registro dos eleitores. Em 1945, primeira eleição realizada após o período do Estado Novo, a obrigatoriedade do alistamento e voto se estendeu a todas as mulheres e estabeleceram-se multas para quem não o fizesse.

Além disso, o alistamento automático se mostrou muito mais eficiente do que em 1932, em virtude do registro em larga escala realizado pelos interventores estaduais e pelos sindicatos. Alvo de inúmeras críticas de parlamentares udenistas, o alistamento "ex-oficio" foi suprimido com o estabelecimento do Novo Código Eleitoral em 1950. A isso, ainda é possível acrescentar outro elemento: tanto o Código de 1932, quanto a "Lei Agamenon", mantiveram a proibição ao voto dos analfabetos.

Dessa forma, a redução nas taxas de analfabetismo, mesmo que bastante lenta, também representava uma alteração significativa no eleitorado. Por outro lado, o aumento no número de votantes ocorria em meio à difusão de argumentos de viés elitista que desqualificavam a capacidade de escolha do novo eleitorado e criticavam a influência do Estado sobre uma massa inconsciente e manipulável. Em 1950, o povo, que agora contava com a participação eleitoral das classes populares, era visto com reservas e desconfiança. Havia a preocupação com o processo democrático diante da percepção da heterogeneidade do eleitorado e do povo.

Havia uma clara distinção: eleitores e cidadãos. Essa distinção se associava a uma geografia política. No interior rural, eleitores seriam cooptados pelo poder federal ao contrário das cidades, onde a presença de cidadãos dificultaria essa prática. 
Interior é onde a pressão governamental, pela violência, pelo engodo e pelo suborno, dirige o pronunciamento dos eleitores. Grandes cidades, é onde o governo por mais que ameace, iluda e procure comprar a consciência dos cidadãos, quase sempre duvida da obtenção de votos, ou antes, nunca os tem para o seu partido e para seus candidatos. (O BRIGADEIRO..., 1950, p. 1)

De acordo com os jornais pesquisados, a "massa irracional", identificada com Getúlio Vargas, não estava preparada para atuar conscientemente no processo eleitoral democrático. Em editorial no qual pretendia-se antecipar o discurso que Getúlio Vargas faria em um encontro a ser realizado naquele dia, no Estádio do Club de Regatas Vasco da Gama, no então Distrito Federal, o jornal afirmou que entre seus apoiadores "são classes bastante numerosas a dos ingênuos, a dos inocentes e dos saudosistas. E também duas outras menos respeitáveis: a dos curiosos e a dos espertos" (O QUE..., 1950, p. 1). De acordo com jornal não era preciso ser adivinho para saber que o "candidato populista", sustentaria o direito a ser facultado ao povo carioca de eleger suas próprias autoridades $^{13}$. Ainda segundo o jornal, da mesma forma seu passado ditatorial e sua desfaçatez não o impediriam de proferir "um discurso liberal, democrático, ungido de legalidade e constitucionalismo", contrariando a tudo que sua figura representava. Ouvir e aceitar tal absurdo se constituiria, portanto, em um problema de memória ou de consciência para o povo.

O nacionalismo proclamado por Vargas, não poderia ser enunciado fora do contexto da participação dos trabalhadores. Em um primeiro momento, sua

\footnotetext{
${ }^{13}$ As discussões em torno do conceito de populismo ainda hoje são motivo de extensa polêmica, compondo não pequena bibliografia. Embora não consideremos este artigo o espaço adequado para o desenvolvimento mais aprofundado deste debate, ressalta-se apenas que os usos deste conceito já permeavam o ambiente político brasileiro desde os anos 30, ora interpretando os populistas como aqueles que adotavam uma política voltada para o povo e em conformidade com os seus interesses, ora classificando-os como uma elite corrupta e amoral que substituía a elite tradicional e cooptava o apoio das massas de forma demagógica, aproveitando-se de sua ignorância para então realizar os seus próprios desejos. Em meados dos anos 50, mais especificamente a partir da publicação do ensaio “O que é o ademarismo?”, de Hélio Jaguaribe (1954), o debate inseriu-se em definitivo nos círculos acadêmicos consolidando o entendimento de que uma política populista estava ligada a um projeto ou governo que supostamente ia ao encontro de alguns desejos das massas ressentidas, na busca de se perpetuar no poder e obter privilégios pessoais. Refinada teoricamente a partir das formulações, nos anos 60, 70 e 80 , de analistas políticos como Francisco Weffort (1978), essa concepção acabou por se tornar um cânone no Brasil. Contudo, nos últimos anos, alguns historiadores e cientistas políticos como Ângela Castro Gomes (2001), ao argumentar, a partir da história cultural, sobre a reciprocidade material e simbólica estabelecida entre os atores políticos, têm colocado em questão a alegada incapacidade das massas, ainda ressaltada por distintas análises.
} 
plataforma nacionalista foi interpretada como inimiga dos interesses dos liberais brasileiros. Estes defendiam um desenvolvimento econômico que acompanhasse a divisão internacional do trabalho, com baixa planificação e presença discreta do Estado na economia, além da manutenção de um regime democrático representativo e elitista. Essa leitura foi balizada pelo caráter nacional e democrático do trabalhismo, traduzido em aspectos "estatizantes" e mesmo "comunistas", subversivos à ordem. Em sua campanha, Getúlio Vargas associou questões de soberania, desenvolvimento econômico e participação popular (GUIMARÃES, 2001).

As posições e pronunciamentos de Vargas também receberam o duro combate de diversos setores da imprensa. No pleito presidencial de 1950, a Tribuna da Imprensa apoiou, com ressalvas, a candidatura do Brigadeiro Eduardo Gomes. Defensor de uma democracia liberal elitista, de defesa de grupos minoritários, Carlos Lacerda argumentava contra a pretensa "vontade da maioria". "Ora, democracia é o respeito à vontade da maioria, sim, mas desde que esta respeite os direitos da minoria, como é de seu dever" (LACERDA, 1950, p. 3). Para o editorialista e parlamentar, Getúlio Vargas não possuía o direito de se candidatar, pois, era um ditador. Quanto à candidatura de Cristiano Machado, a cobertura da Tribuna da Imprensa foi marcada pelo silêncio.

Por sua vez, o jornal $A$ Noite repercutiu em suas páginas argumentos referentes à viabilidade da democracia. Antônio Vieira de Melo, editorialista do jornal, mostrando-se diletante em relação à livre concorrência aos cargos eletivos, escreveu: "Tudo isso teoricamente parece muito bonito: Qualquer cidadão com direito a se candidatar! Mas na prática, o resultado são as Câmaras incapazes, o eleitorado impossibilitado de julgar, a coisa pública confiada a inexperientes" (MELO, 1950, p. 3). Publicado em um momento no qual o resultado das eleições já indicava a vitória de Getúlio Vargas, o editorial "O Drama da Democracia”, contestou a participação popular nas eleições.

Apresentada como um feito negativo à democracia, a eleição de Vargas foi problematizada pelo viés do insucesso das elites. O jornal criticou a postura desinteressada das elites dirigentes com relação à candidatura de Vargas. “Desgraçadamente... a cegueira de uma elite dirigente com vocação suicida tudo 
conspirou no sentido de atirar o país nos perigosos rumos que marcha e com que desenlace final ninguém sabe" (O DRAMA..., 1950, p. 3). De acordo com os opositores de Getúlio Vargas, somente a consolidação da democracia sanaria o grave problema de conscientização do povo brasileiro, levando-o a nunca mais cometer o "erro" de eleger um ditador. O conceito de povo mobilizado pelo jornal, portanto, além de conter um tom moral, pois representaria aqueles que deveriam votar 'corretamente' e de acordo com os pressupostos elitistas do jornal, indicava também uma teorização que apontava para o caráter transitório do momento e a necessidade de consolidar o regime democrático.

A temática do desenvolvimento também encontrou repercussão nos jornais analisados. De uma forma mais ampla, estes defendiam o desenvolvimento agrícola como trampolim para a industrialização, divergindo do discurso varguista em relação aos moldes em que deveria se dar o desenvolvimento industrial. Os grupos liberais viam a entrada de capitais estrangeiros e a baixa intervenção estatal como o caminho para o desenvolvimento brasileiro. Para os opositores de Vargas, a criação de um parque industrial se justificava somente mediante a formação prévia de um mercado interno forte, que elevasse o poder aquisitivo da população. Esse mercado seria formado a partir do desenvolvimento da produção agrária. O progresso técnico no campo e seu desenvolvimento seriam, portanto, precondições para o avanço industrial brasileiro.

Ainda que o cenário estivesse marcado pela hegemonia do discurso industrialista, os setores ruralistas e seus aliados demonstravam toda sua força nas disputas pelo conceito de desenvolvimento. A Tribuna da Imprensa rechaçou uma possível supremacia do industrialismo no Brasil. Este exerceria mudanças na vida do operariado e faria com que os brasileiros perdessem a essência de sua liberdade em virtude dos males sociais que poderia vir a causar. Além disso, o protecionismo às indústrias, central na proposta varguista, era uma das "causas da drenagem que sofre a agricultura em seus elementos mais importantes da produção" (LACERDA, 1950, p. 3).

Para os articulistas de A Noite, Tribuna da Imprensa e Correio da Manhã, a relação entre agricultura e industrialização possuía caráter complementar e não 
representavam, de maneira alguma, uma incongruência. O Correio da Manhã fez diversas referências à nossa "verdadeira realidade" - a agrária - e, dessa maneira, criticou a industrialização enquanto único meio de enriquecimento da nação. 0 "rumo urbano" que estaria sendo proposto por alguns dirigentes, era avaliado enquanto algo 'demagógico', já que estes encontrariam na "massa operária”, um farto manancial de voto. A percepção que os jornais possuíam do povo e de sua suposta capacidade política influenciava o idioma político utilizado para tratar do desenvolvimento econômico.

Dentro do idioma político utilizado por Vargas em seu projeto de governo, desenvolvimento significava industrialização, eletrificação e ampliação das redes de transportes em geral. Esses aspectos foram tratados de maneira particular em cada região visitada por sua campanha (REGAL, 2007). Entretanto, desde o final do Estado Novo, o tema do desenvolvimento já assumira um caráter nacional. Essa questão apareceu, sobretudo, nos debates em torno da criação da Companhia Vale do Rio Doce, da Fábrica Nacional de Motores e da Companhia Siderúrgica Nacional, estatais surgidas a partir de uma visão estratégica na qual o Estado assumiria o controle dos setores produtores de insumos básicos para o desenvolvimento e independência econômica nacional. Somado a esse debate, encontrava-se também o tema da nacionalização das riquezas naturais e dos recursos do subsolo. Embora o discurso varguista apontasse para a limitação da atuação das grandes empresas internacionais em assuntos estratégicos, seu projeto desenvolvimentista não colocava em risco a participação de capitais estrangeiros em diversos setores da economia nacional.

Novamente enfatizando a relação entre texto e contexto, parole e langue, explicitadas por Koselleck e Pocock, bem como as intenções/efeitos dos atos de fala, as formulações teóricas de Eugênio Gudin e Roberto Simonsen, explicitadas no famoso debate de 1944/45 14 , continuariam agindo sobre outros contextos

\footnotetext{
${ }^{14}$ Realizado no âmbito da Comissão de Planejamento Econômico do governo Vargas, o embate entre o industrial Roberto Simonsen e o economista liberal Eugenio Gudin, considerado um dos mais importantes debates econômicos do país, basicamente versava sobre os limites de atuação do Estado na economia e a necessidade, ou não de se investir na industrialização do país. Enquanto Gudin defendia a teoria das vantagens comparativas, a partir da qual países de vocação agrária como o Brasil deveriam apostar nas suas potencialidades específicas, e desta forma, não investir pesadamente na industrialização, Simonsen acreditava que sem a concretização da passagem do capitalismo mercantil para a fase industrial, o processo de desenvolvimento capitalista se veria impossibilitado (BIELSCHOWSKY, 1988; MARINGONI, 2012).
} 
linguísticos. Se a campanha de Vargas preconizava a industrialização como meio de desenvolver o país, seus opositores, mais próximos ao postulado liberal, e dos setores privados, defendiam, entretanto, a vocação agrária do Brasil, e, portanto, nela a saída para seu desenvolvimento material e industrial. A ruptura com a estrutura agrária e o afrouxamento dos mecanismos de coerção da força de trabalho urbana (FERNANDES, 2006), que poderiam ser vistos como medidas necessárias para a construção de um desenvolvimento liberal à americana (VIANNA, 2004), não figuravam nos idiomas políticos dos opositores liberais de Vargas. Isso se devia ao receio de que as possíveis consequências de uma mudança social excessivamente profunda, e sem maiores possibilidades de controle, afetassem seus privilégios e a ordem social.

Esse mesmo embate entre interpretações vistas como anacrônicas e a realidade vivida, marcou os debates em torno da ideia de democracia. Embora se apresentassem como defensores das liberdades individuais inerentes a uma nova época, não mais vinculada a uma experiência ditatorial, os jornais se mostraram reticentes quanto à efetiva ampliação da participação popular na cena eleitoral. Apresentavam uma perspectiva democrática de viés elitista que, ao invés de apontar para um novo horizonte de expectativas, remontava a uma concepção de democracia presente no espaço de experiências dos primeiros anos da república. Argumentavam sobre o papel crucial que deveriam exercer os "grupos dirigentes" da nação no processo de "conscientização" de uma nova massa de eleitores.

Em nenhum momento, ao longo da campanha de 1950, se considera a capacidade de escolha dessa massa "irracional" e "deseducada", sobretudo quando vinculada ao campo varguista. Dessa forma, os interlocutores dos discursos presentes nos jornais não são os novos eleitores que acabaram de entrar no jogo eleitoral, mas aqueles “cidadãos conscientes” capazes de formálos e liderá-los e que, assim, impediriam a ação "manipuladora e opressora" do varguismo. A avaliação feita pelos jornais da capacidade do povo se baseava na leitura de que, sob os anos do Estado Novo e dos governos de Vargas, o povo sofreu um processo de "deseducação". 
Representante de grande influência na linguagem política da década de 1950, os idiomas políticos vinculados à UDN, analisados por Jorge Chaloub (2019), enunciavam certa centralidade no Estado e em seu ordenamento jurídico. Esses posicionamentos liberais evidenciavam o temor de verem bem-sucedido qualquer projeto que desse margem ao interesse excessivamente livre das massas, implicando em sua participação. A transformação por meio do protagonismo popular, com toda a sua imprevisibilidade, poderia levar à destruição de antigas relações de comando e privilégio, em narrativa preocupante aos olhos dos que estavam há muito acostumados a determinada ordem.

Democracia e desenvolvimento: o caminho para a efetiva soberania nacional

O ambiente político às vésperas da eleição de 1955 era de agitação. O expresidente Getúlio Vargas cometera suicídio em 24 de agosto 1954, após um período de governo marcado por contumaz oposição da maior parte da grande imprensa. A adoção de uma política de viés nacionalista também desagradou, em muito, o grupo militar que pretendia uma aproximação maior ao capital externo. O envolvimento de elementos de sua guarda pessoal no atentado sofrido pelo jornalista Carlos Lacerda, em agosto de 1954, foi o estopim de uma crise que levaria a esse desfecho fatal.

O vice-presidente Café Filho assumiu em seu lugar, com a tarefa de conduzir o país até as eleições seguintes. Após uma tentativa frustrada de articulação de uma candidatura única, por parte dos ministros militares, e de alguns lançamentos prematuros, quatro candidatos registraram seus nomes: Juscelino Kubitschek, pelo PSD-PTB, Juarez Távora, por uma frente partidária que contava com o apoio da UDN, Adhemar de Barros, pelo PSP e Plínio Salgado, pelo PRP, legenda herdeira da Ação Integralista Brasileira. Já para a vice-presidência, eleição que então se realizava em separado, candidataram-se João Goulart, pelo PTB, Milton Campos, pela UDN, e Danton Coelho, pelo PSP, para um pleito que se realizaria em 3 de outubro de 1955. 
A campanha eleitoral não transcorreu com tranquilidade, sendo marcada por diversas tentativas de adiamentos e cancelamentos que mantiveram a realização do pleito indefinida até os últimos momentos. Em apenas dois meses, do início de agosto até 03 de outubro, pode-se registrar, uma tentativa de aprovação de uma emenda parlamentarista, a votação da proposta de alteração da regra eleitoral para instituir-se a necessidade de maioria absoluta dos votos para a vitória no pleito e um projeto de implantação do sistema colegiado. Inúmeras discussões acerca de qual seria o modelo de cédula eleitoral mais adequado contra possíveis fraudes, que incluíam até uma proposta de sujar de tinta o dedo de todos os eleitores no ato da votação para não haver duplicidade de votos, movimentaram a Câmara e o Senado até a aprovação definitiva da cédula única, a partir de então confeccionada pelo TSE (NICOLAU, 2002, p. 52).

Medida nitidamente democratizante, a criação da nova cédula reduzia a probabilidade de coação e controle do voto a que estavam especialmente submetidas as populações do interior do país. Supunha-se o reconhecimento, ao menos em nível eleitoral, dos reais desejos e vontades do povo. Muitas também foram as tentativas de cassação dos direitos políticos de Juscelino Kubitschek e de João Goulart por suposto envolvimento com comunistas, naquele momento na ilegalidade, ou mesmo com um complô peronista (MIRANDA, 2010).

Naquele momento, os grupos que haviam atuado intensamente nas pressões ao governo Vargas, temiam a volta, pelo voto, de setores ligados ao "varguismo" ao governo executivo. Diante de um alegado "perigo à democracia", seus opositores procuravam encontrar soluções legais e extralegais para que candidatos fossem desqualificados e a realização do pleito fosse inviabilizada ou desmoralizada.

Nos editoriais da Tribuna da Imprensa, o principal alvo de críticas era João Goulart, "o maior de todos os demagogos". Suas ligações com uma "oligarquia de assassinos" impossibilitariam sua inscrição ao pleito. Para o jornal, nenhum dos candidatos detinha os atributos necessários para exercer a presidência da República. Até mesmo a candidatura de Juarez Távora, apoiada pela UDN, era encarada com muitas ressalvas em virtude de sua suposta aproximação com 
elementos da "estrutura de poder estabelecida". Este cenário levou a Tribuna da Imprensa a incentivar abertamente a abstenção em massa. Somente quinze dias antes do pleito, o jornal resolveu ingressar na campanha de Juarez Távora "em prol do bem comum". Contudo, o editorialista, Carlos Lacerda, deixou evidentes suas ressalvas. "Reservo-me o direito de continuar nossa pregação de uma reforma de emergência nas instituições nacionais se pela força da corrupção e da desordem moral e material do país não for vitoriosa, a 03 de outubro a candidatura Juarez Távora" (O NOSSO... 1955, p. 3)

Última Hora, por sua vez, procurou afirmar sua isenção defendendo a realização das eleições sem quaisquer adiamentos e incentivando o comparecimento em massa às urnas. Contudo, dentre os candidatos à presidência, demonstrou simpatia com os "populares". Juscelino Kubitschek foi visto como um nome interpartidário, capaz de unir correntes distintas, destruir ódios e promover a paz e a ordem necessária ao equilíbrio da nação. Já Adhemar de Barros, candidato "popular-trabalhista", era avaliado como tendo suas propostas vinculadas ao interesse do povo. Ao se apresentar como herdeiro e fiel seguidor dos ideais de Vargas, Última Hora entendia que, independentemente de nomes, o fundamental era que seu projeto de governo permanecesse presente nos programas dos candidatos. Dessa forma, a nação brasileira, o progresso nacional e o regime democrático seriam os grandes vencedores do processo eleitoral.

As páginas do Correio da Manhã, também não expressaram claramente uma posição em favor de qualquer candidato. Dessa maneira, ao povo, facultavase o direito de votar em quem quisesse. Contudo, enquanto os demais candidatos foram praticamente ignorados, o tom das críticas foi sempre mais elevado em relação a Juarez Távora do que em relação a Juscelino Kubitschek. Seu apregoado "espírito democrático" e um projeto de governo que visava o desenvolvimento nacional através do investimento na indústria contribuíram para que ele recebesse o apoio de alguns colunistas do Correio da Manhã, como Augusto Frederico Schmidt, a título de opinião pessoal. Em suas palavras, 
Juscelino Kubitschek seria "um homem de hoje, com a aceleração deste tempo" (SCHMIDT, 1955a, p. 2) $)^{15}$.

Desenvolvimento nacional foi a grande mola propulsora dos debates políticos em 1955. Apesar de ser visto sob diferentes aspectos, era opinião consensual que este se constituía na grande saída para que o país encontrasse a paz social e o equilíbrio econômico. O desenvolvimento, que naquele momento político era interpretado como desenvolvimento econômico e industrial, seria de vital importância para que o Brasil pudesse figurar entre as grandes nações do mundo. ${ }^{16}$ Todos os benefícios sociais só poderiam existir se viessem atrelados a ele. Contudo, a polêmica, girava em torno de como o desenvolvimento poderia ser alcançado.

As propostas de Carlos Lacerda e da Tribuna da Imprensa iam de encontro às formulações da CEPAL ${ }^{17}$, que já no início dos anos 1950 apostavam no apoio estatal para a busca do desenvolvimento. Para o jornal, a participação do Estado na gestão de empresas representava um atraso que impedia a entrada de investimentos estrangeiros que poderiam fomentar a economia nacional. Além disso, diante da profunda crise política, social e econômica vivida pelo Estado brasileiro, somente um regime de emergência, com um executivo forte, poderia

\footnotetext{
${ }^{15}$ Cabe ressaltar que essa propalada imparcialidade foi válida apenas para os candidatos à presidência, já que João Goulart, foi alvo de uma dura oposição do Correio Manhã em virtude de suas ligações com o varguismo. Caso fosse conferido um mandato popular ao antigo "aprendiz de feiticeiro nas mãos do Sr. Getúlio Vargas", seria fundamental que se estabelecessem meios para impedir que ele pudesse "voltar a controlar, com seus pelegos, o ministério do trabalho" no intuito de criar uma CGT ministerialista (LIÇÕES..., 1955, p. 6). Para o jornal, em última instância, João Goulart encarnava um projeto de governo totalitário nos moldes do peronismo na Argentina.

${ }^{16}$ Entretanto, não é demais lembrar das relações entre o projeto nacional-desenvolvimentista de JK e o projeto ruralista que buscava articular, preservar e ampliar os interesses rurais durante o processo de industrialização (MOREIRA, 2003).

${ }^{17}$ Criada em 1948, com sede em Santiago no Chile, a CEPAL procurava desenvolver soluções para a transformação da situação de subdesenvolvimento dos países latino-americanos. Para seus articuladores, como Raul Prebisch e o brasileiro Celso Furtado, isso só se daria com o rompimento da divisão internacional do trabalho até então estabelecida. A disparidade existente entre os países centrais, produtores de bens industriais, e os chamados periféricos tradicionalmente produtores de bens primários, forçava constantes transferências de valores aos países centrais, o que "deteriorava os termos de troca", impedindo assim o seu desenvolvimento. Dessa forma, a proposta cepalina no Brasil acreditava que sem a montagem de um parque industrial, com o fomento da produção feita pelo estado, o país jamais se modernizaria. Diante das dificuldades de competição entre o capital nacional e o estrangeiro, o apoio estatal seria fundamental para se "queimar" etapas no processo de industrialização e desenvolvimento (BIELSCHOWSKY, 1988).
} 
corrigir os defeitos da democracia brasileira. Sem a "preparação inicial" de uma reforma constitucional, o processo de desenvolvimento começaria de forma distorcida.

O Correio da Manhã divergia dessa posição ao afirmar que o desenvolvimento nacional só poderia ser promovido em um ambiente de ordem interna e de perfeito funcionamento legal. Para evitar que atmosfera "golpista" e as incertezas políticas afetassem as importações e as exportações, era de suma importância a manutenção da democracia vigente e de suas normas. Com relação à participação estatal na economia, a posição do Correio da Manhã se aproximava da Tribuna da Imprensa, visto que a entendia como um fator capaz de sufocar investimentos particulares e de impedir a livre concorrência. Sem esta, o país não estaria qualificado para receber capitais e incentivos estrangeiros. As palavras do colunista Augusto Frederico Schmidt, defensor do desenvolvimento como grande solução nacional, pareciam sintetizar a posição do Correio da Manhã quanto à participação do capital estrangeiro na economia nacional.

Considero que não podemos impedir que as firmas estrangeiras venham ao Brasil para negociar entre nós. Neste capítulo da discriminação nacionalista para empresas mercantis e outras, o nosso interesse indubitável é o da manutenção das portas abertas a quem quiser vir trabalhar em nossa casa. Só temos com isso lucro e estímulo para os nacionais que conhecerão uma concorrência que só poderá thes ser profícua. (SCHMIDT, 1955b, p. 2)

Última Hora também criticava a criação de uma atmosfera de crise política, pois era a confiança dos meios produtivos nacionais e dos investidores internacionais na ordem democrática que possibilitaria a criação de novos negócios e investimentos em benefício do desenvolvimento nacional. Assim como os economistas da CEPAL, entendia que a ação do Estado como investidor direto e a gestão dos recursos naturais, sob o ponto de vista nacionalista, eram centrais para a superação de etapas no desenvolvimento nacional. Contudo, a participação do capital externo na economia era importante. Os benefícios do desenvolvimento, "não poderão tornar-se realidade, se no tocante a técnica escolhermos o caminho do isolacionismo, ou seja, do nacionalismo radical, jacobino, que se atrita com a salutar política de cooperação internacional 
indispensável ao desenvolvimento da economia industrial nos países como o Brasil” (SINAIS..., 1955, p. 4)

Neste aspecto, o jornal dirigido por Samuel Wainer mantinha uma opinião que ia ao encontro de algumas formulações elaboradas no seio do Instituto Superior de Estudos Brasileiros (ISEB), cujos intelectuais se propunham a estudar os problemas fundamentais brasileiros e agir como instrumento de uma ação eficaz na política brasileira (MIRANDA, 2010b) ${ }^{18}$. Em um artigo publicado na edição de abril/agosto de 1955 da revista Cadernos de Nosso Tempo, editada pelo instituto, Hermes Lima (1988) compartilha da posição defendida em Última Hora. "O nacionalismo verdadeiro nada tem de jacobino, não se arreceia da colaboração estrangeira. Não implica de modo algum em posição isolacionista". Da mesma forma, a hostilidade ao capital estrangeiro foi classificada pelo autor como produto da ignorância e da má-fé.

Augusto Schmidt, colunista do Correio da Manhã foi ainda mais incisivo na crítica aos nacionalistas "jacobinos". Para ele, a participação do capital estrangeiro na economia nacional, mais do que tolerada, deveria ser estimulada, pois o desenvolvimento nacional era o fim último e único objetivo de todos. Argumento similar foi desenvolvido, anos depois, por Hélio Jaguaribe, importante pensador isebiano que propunha um nacionalismo de fins, que valorizava a utilização de todos os meios apropriados para a realização do desenvolvimento. Assim, desde que se revelassem eficazes, pouco importava a origem dos recursos empregados para esse fim (JAGUARIBE, 1958, p. 51). Sua visão bastante tolerante ao capital estrangeiro recebeu inúmeras críticas dentro do próprio ISEB, revelando o caráter plural das formulações do instituto em torno da proposta nacionalista.

Editorialistas e colunistas dos distintos órgãos pesquisados tentavam convencer os leitores de suas propostas, adotando a estratégia de desqualificar opiniões divergentes e classificá-las como dissonantes da vontade da nação. E isso se dava diante de uma comunidade argumentativa marcada pela mobilização de conceitos antitéticos e assimétricos que determinavam posições

\footnotetext{
${ }^{18}$ Para uma discussão mais ampla sobre o debate intelectual presente no Iseb, ver: PAIVA, Vanilda. Paulo Freire e o nacionalismo desenvolvimentista. Rio de Janeiro: civilização brasileira, 1980; PECAULT, Daniel. Os intelectuais e a política no Brasil. São Paulo: Ática, 1990; TOLEDO, Caio Navarro. Iseb: fábrica de ideologias. São Paulo: Ática, 1977.
} 
segundo critérios que, ao adversário político só restaria a recusa e a negação. ${ }^{19}$ Pois, como se sabe, a "vontade da nação" depende de seus intérpretes e beneficiários.

Na Tribuna da Imprensa transpareceu a ideia de que a nação estava desencantada com as leis vigentes. Tais leis não se mostravam capazes de retirar do poder uma oligarquia que, na avaliação do jornal, fazia uso de seus privilégios para sugar as riquezas do país, aproveitando-se das massas "manipuladas" e “inconscientes” para 'tiranizar' as parcelas 'conscientes' da população e se perpetuar no poder. Diferente da eleição anterior, parcelas conscientes eram vislumbradas no interior do povo. Parcelas estas que eram vítimas das massas dentro do arranjo democrático vigente. Diante da deterioração de suas instituições políticas e do constante desrespeito aos valores morais, segundo o jornal, o Brasil ainda não podia se afirmar em definitivo como nação.

Nas páginas do Última Hora se expressou opinião radicalmente oposta. A deseducação das massas poderia, em alguns casos, conduzir a erros. Contudo, naquele momento, a nação já estaria plenamente consciente de seus direitos e de sua capacidade de transformação da realidade social. "O povo quer, impõe a continuação da obra de pacífico aprimoramento das instituições, ao mesmo tempo em que condena todos os fomentadores de agitação a serviço consciente ou inconsciente, mas sempre a serviço de interesses antinacionais" (NOSSA..., 1955, p. 4).

A manutenção das instituições democráticas e a garantia do desenvolvimento econômico nacional seriam fundamentais para a afirmação, em definitivo, do Brasil como grande nação. Esta não existiria sem uma soberania plena, que só poderia ser exercida quando se tivesse condições econômicas para tal. Nesse ponto, os editoriais do Correio da Manhã são taxativos. "Tudo o que de grande e heroico é necessário fazer para transformar o Brasil numa nação, e construí-lo como tal, depende fundamentalmente da sobrevivência do regime" (PRÉLIO..., 1955, P. 6).

\footnotetext{
19 Sobre os conceitos assimétricos e antitéticos, ver KOSELLECK, 2006. Para o historiador Lucien Febvre (1998), as palavras não devem ser estudadas em si mesmas, mas sim fazendo relações com outras palavras que concordam ou se opõem a elas formando pares.
} 
O Correio da Manhã entendia que o regime democrático não era o ideal. Forjada no seio da ditadura estadonovista, a democracia brasileira ainda era muito recente. Contudo, só com o exercício constante do voto a nação brasileira poderia chegar ao nível das grandes democracias do mundo. A democracia assumia, tal qual o conceito de desenvolvimento, caráter transitório ou de aceleração do tempo. Pois seria sua dinâmica intrínseca que iria conferir racionalidade e a modernização necessárias a uma grande nação. O regime democrático e o voto, portanto, seriam os responsáveis por fazerem avançar a parcela "consciente" do povo frente às massas "deseducadas". Nesse sentido, qualquer ação que ferisse a Constituição vigente, como as tentativas de se inviabilizar o pleito e os pretextos visando um golpe de Estado, colocariam em risco a democracia, sendo um obstáculo ao desenvolvimento e ao processo histórico. O único objetivo dos “falsos pretextos" golpistas era cooptar o apoio da sociedade para suas intenções antidemocráticas.

Com uma opinião mais otimista do que a expressa pelo Correio da Manhã, os editoriais do Última Hora comemoravam o caminho que vinha sendo trilhado pela democracia brasileira. Valorizando fundamentalmente o advento das massas à política e sua conscientização de que a luta democrática deveria ser a luta de toda a nação. O grande responsável pelo sucesso do regime seria o povo que, através da liderança exercida por Getúlio Vargas, entendeu que não podia se desviar do caminho da legalidade, da democracia e da defesa dos interesses da nação. Enquanto o Correio da Manhã e outros jornais buscavam obliterar o legado político de Vargas, apontando para uma democracia procedimental, a Última Hora politizava a democratização do país. O posicionamento do jornal, neste caso, apontava para uma compreensão distinta do conceito de democracia, e por conseguinte, do conceito de povo.

Ao passo que o Correio da Manhã acreditava que o exercício do voto seria o responsável pela maturidade do povo, conferindo-lhe racionalidade extrínseca a seu conjunto, a Última Hora creditava esse processo à liderança de Vargas e de seu legado popular. Ou seja, atribuía-se a racionalidade do povo à interação político-ideológica com o projeto trabalhista. Isso despertara o ódio nos "democratas de cartola" que tentavam impedir a perda de seus privilégios, 
através da incitação ao golpe de Estado com pretextos e 'sem o menor fundamento'. Ao comentar o desfecho do processo eleitoral, a Última Hora, afirmou que a democracia brasileira deu um exemplo de maturidade, legalidade e respeito à ordem pública que se igualou ao nível das grandes democracias do mundo. "Foi-se o tempo em que com suas máscaras vistosas de democratas impávidos e suas lábias de acusadores públicos, eles ainda iludiam as massas na sua ingenuidade cívica... Hoje o povo despertou" (PELEGOS..., 1955, p. 4).

Por outro lado, a Tribuna da Imprensa novamente expressou uma opinião oposta pautada em argumentos morais. Para o jornal, todo o caminho percorrido pela democracia nacional se encontrava corrompido pela fraude, pela corrupção e pelo poder das oligarquias. Defender o regime e o pleito eleitoral nessas condições seria uma atitude de "democratas-mirins", "democratas da boca para fora". Uma "verdadeira democracia" era

o regime dos melhores: nunca o dos ladrões e dos demagogos. Por exigir pressupostos de ordem moral a democracia impõe uma sanção aos maus governos - a derrota eleitoral. Aqui o que se vê, é exatamente o oposto. Eles se eternizam no poder, pois fazem dos cofres públicos e do engodo as almas de sua política continuísta. (A LEGALIDADE..., 1955, p. 4)

Desde o governo Vargas, avaliava o jornal, uma oligarquia de demagogos em busca de seus próprios interesses, "deseducava” o povo para que votasse em desacordo com sua própria consciência. A democracia era vista como um governo que emanava da vontade do povo, mas quando o povo votava sem saber que estava sendo enganado, construía uma "democracia de mentira". Carlos Lacerda entendia que a democracia não passava de um meio para se atingir o fim último que era o bem comum. Este se baseava em princípios éticos e morais - selecionados por ele próprio - do convívio social. Nesse sentido, o processo democrático puro só poderia se reiniciar após a implantação de um regime de emergência e a "desintoxicação" das instituições.

Em meio ao conturbado contexto eleitoral, os conceitos de nação, desenvolvimento e democracia, se relacionavam entre si formando uma espécie de círculo virtuoso. Atravessando tais conceitos, a percepção e a qualificação das capacidades políticas do povo demarcavam as fronteiras entre projetos e 
idiomas políticos distintos. A despeito da polissemia dos conceitos, na opinião praticamente consensual dos órgãos de imprensa envolvidos no debate acerca do pleito de 1955, seria necessário um ambiente de plena democracia, oriundo da vontade 'consciente' de todos, para que o país seguisse os rumos do desenvolvimento. Esse seria o único caminho para o Brasil se constituir realmente em uma nação totalmente soberana, já que, assim, não dependeria mais economicamente de nenhuma outra nação. Os articulistas, colunistas e redatores do Correio da Manhã, da Tribuna da Imprensa e da Última Hora concordavam com essa linha de argumentação. Entretanto, o que diferiu nos seus pensamentos foi a forma como os conceitos foram apreendidos e incorporados à realidade brasileira.

\section{O pleito de 1960 e a "maioridade" do povo}

As eleições de 1960, último pleito presidencial em análise neste artigo, foram marcadas pela herança do governo de Juscelino Kubistchek. A elevada inflação e a mobilização das massas no campo e na cidade influenciaram na escolha dos candidatos à sucessão presidencial. Carlos Lacerda e a "Banda de Música" rechaçaram a tentativa de aproximação entre PSD/PTB e a UDN, encorpando as articulações em torno do lançamento de Jânio Quadros, governador de São Paulo, como candidato de oposição à aliança PSD/PTB. Além de Quadros, Adhemar de Barros novamente se lançou como candidato de oposição pelo PSP. A chapa governista, por sua vez, trazia como candidato à presidência o Marechal Henrique Teixeira Lott e João Goulart para vice, a despeito da resistência de grupos conservadores do PSD e setores militares.

A campanha de Lott orientou-se pela defesa da bandeira do nacionalismo econômico e atacou a "influência maléfica de grupos econômicos e financeiros" nas eleições. O apelo à moralidade administrativa e o combate aos rumos desenvolvimentistas do plano de metas estiveram na base da campanha de Jânio Quadros. Utilizando como símbolo político uma vassoura, prometia varrer toda a corrupção da política brasileira. O apoio da UDN a Quadros marcou uma virada no discurso udenista. Desde sua fundação, o partido questionava a capacidade política das camadas subalternas. Contudo, no pleito de 1960, 
voltava-se para esses mesmos setores em busca de apoio eleitoral. A Campanha de Jânio Quadros valorizava a "imensa" e "sensível consciência de mudança no eleitorado", e via nesse processo o caminho para sua vitória. ${ }^{20}$ Após sua vitória no pleito, Jânio inclusive apontaria para a necessidade de se multiplicarem "órgãos da mecânica democrática, fazendo que surjam, ao lado dos tradicionais, outros, mais próximos das massas" (LOUREIRO, 2009, p. 190).

Em verdade, foram muitas as divergências entre as propostas de Jânio Quadros e as de amplos setores da UDN. O candidato defendia a “industrialização" da agricultura, a nacionalização da energia, o fortalecimento da Petrobrás e a garantia do monopólio estatal sobre o petróleo. Essas ideias, somadas a propostas de controle das remessas de lucros ao exterior e de uma política externa não alinhada e mais independente, aproximavam seu projeto de campanha das teses de seus opositores, entre eles o próprio PTB e, ao mesmo tempo o afastavam da UDN, principal partido de sustentação de sua campanha²1. Diante desse cenário, à primeira vista, o apoio da UDN à campanha de Quadros pode parecer fruto apenas do cálculo eleitoral. Contudo, acreditamos que também se articulava a uma compreensão acerca da nova configuração do eleitorado e suas demandas. Assim, essa "adaptação" à nova realidade se articularia a uma postura de valorização da participação popular.

Na imprensa, a difícil associação entre os programas dos partidos e as propostas de seus candidatos se evidenciou nitidamente. Os editoriais do Jornal do Brasilque, ao longo do governo Kubitschek, reverberaram muitas acusações de desmandos na construção de Brasília e de corrupção, insistiam na falta de distinção entre os partidos e na excessiva semelhança entre os programas de governo dos candidatos. Nenhum deles se apresentava como reformador das

\footnotetext{
20 A respeito da trajetória política de Jânio Quadros ver: ARNT, Ricardo. Jânio Quadros: O prometeu de Vila Maria. Rio de Janeiro: Ediouro, 2004; e BENEVIDES, Maria Vitória de Mesquita. A UDN e o udenismo: ambiguidades do liberalismo brasileiro. Rio de Janeiro: Paz e Terra, 1981.

${ }^{21}$ Não custa lembrar que a manutenção de Henrique Lott como ministro da Guerra, ao longo de todo o governo Kubitschek, se deu com o apoio da corrente legalista do exército, mas veio associada à nomeação de militares para cargos-chave na administração de setores estratégicos e empresas estatais como a Petrobrás, revelando o apoio de parte das Forças Armadas à presença do Estado enquanto impulsionador, ou ao menos regulador de determinados setores econômicos. Em verdade, o discurso nacionalista era amplo e continha várias nuances, aglutinando ao seu redor correntes ideológicas de todo o espectro político, presentes nos mais diversos setores da sociedade, de sindicatos a militares, partidos e intelectuais.
} 
estruturas políticas, econômicas e sociais do Brasil. Diante disso, a opção que se colocava era a escolha entre indivíduos: um militar que ainda estava se adaptando à prática política e continuador do governo anterior ou o homem eficiente, com grande popularidade e preocupado com a moralidade política do país como Jânio Quadros.

Ao declarar seu voto ao ex-governador de São Paulo, o Jornal do Brasil publicou que "a sua eleição representará a subida ao Poder, no Brasil, de uma nova geração de políticos - o inevitável arquivamento dos velhos cacoetes e dos hábitos anacrônicos que fizeram a Nação marcar passo durante muito tempo" (O PROGRAMA..., 1960, p. 3). O Correio da Manhã corroborou as posições do Jornal do Brasil, também fundamentando seu apoio a Quadros mais em suas características pessoais do que em um conjunto de propostas partidárias. Como presidente da República, Jânio seria um "terremoto cívico que caíra sobre esta Nação" (JÂNIO..., 1960, p. 16).

O desenvolvimento econômico alcançado no período do governo Kubitschek não foi questionado pelos editoriais do Correio da Manhã, tampouco pelo Jornal do Brasil, que considerava inegável o avanço nacional. Este alçara o país a uma condição intermediária entre os países desenvolvidos e os subdesenvolvidos. A crítica recaía sobre a corrupção do governo e os erros administrativos, daí a necessidade de um choque de moralidade com a entrada de Jânio Quadros. Ainda assim, uma nova pauta de questões ligadas ao desenvolvimento ganhara cada vez mais repercussão no final dos anos 50.

Após o sucesso da experiência revolucionária de Cuba em 1959, reforçaram-se as preocupações em torno da carestia e das desigualdades econômicas. A América Latina inseriu-se no horizonte das preocupações estratégicas dos Estados Unidos que passaram a propor, em encontros internacionais, planos de desenvolvimento social que privilegiavam setores de assistência, habitação e educação, fundamentais na preparação e prevenção de uma autêntica vida democrática. Em março de 1961, após a chegada do democrata John F. Kennedy ao governo dos Estados Unidos, seria lançado um programa de cooperação econômica para os países da América Latina, denominado Aliança para Progresso. A partir de seus três pilares, 
desenvolvimento econômico e social, mudanças estruturais e "democratização política”, o projeto se propunha a alterar a realidade de subdesenvolvimento do continente através de uma "revolução pacífica", "democrática" e solidária (HOROWITZ, 1971). Indo ao encontro dessa perspectiva, ambos os jornais realçaram a necessidade premente de implementação de um projeto de desenvolvimento social, que viesse atrelado aos avanços econômicos.

Ao comentar as propostas norte-americanas presentes na Ata de Bogotá22, o editorial do dia 6 de setembro de 1960 do Correio da Manhã destacou a importância da luta contra o analfabetismo, defendendo a educação secundária e técnica. Enfrentar o futuro sem educação, sem um lar decente, sem real esperança de melhorar sua situação econômica, poderia conduzir o homem à agitação extremista. Nesse sentido, a necessidade de uma distribuição mais justa das terras se tornava evidente. Essa leitura coadunava a percepção de que as massas, "manipuláveis" e suscetíveis a discursos "demagógicos" estariam sujeitas à sedução comunista. Através de seus editoriais, o Correio da Manhã reiterou defesa de reformas "indispensáveis para o Brasil”.

O caso típico é a da reforma agrária, que temos surrado sem descanso nestas colunas, principalmente desde que o governo Vargas criou a Comissão Nacional da Política Agrária. No entanto nenhum governo, nem de Getúlio nem de Café Filho ou este, jamais levou a sério, nem mínimo que fosse, a reforma agrária. Ora, é impossível industrializar um país com um regime agrícola feudal, como existe no Brasil do Norte e do Nordeste. (ATA..., 1960, p. 6)

Para o Correio da Manhã, o Brasil era uma nação eminentemente agrícola. Assim, era imperativo modernizar e industrializar a agricultura com o intuito de assegurar as condições básicas para a criação de um parque industrial. Em função do descompasso entre a estrutura agrária e a industrial, "rareiam os alimentos, os preços sobrem, os homens do campo abandonam o interior" (COERÊNCIA..., 1960, p. 6). Os editoriais do Jornal do Brasil atribuíram essa falta

\footnotetext{
22 O texto da Ata de Bogotá foi o resultado da última das três reuniões do chamado "Comitê dos 21", um desdobramento da Operação Pan americana (OPA) dentro da Organização dos Estados Americanos. Nele, com o apoio dos Estados Unidos, se propunham novas medidas de cooperação econômica entre os países americanos, através de ações que proporcionassem o desenvolvimento econômico de forma atrelada a questões sociais específicas das diversas conjunturas regionais. Ver: SILVA, Alexandra de Melo. A política externa de JK: a operação Pan-Americana. Rio de Janeiro: FGV/CPDOC, 1992. p. 37-40. (Texto CPDOC).
} 
de equilíbrio à ausência de liderança e de renovação dos métodos de trabalho. Isso levou a agricultura a perder o comando do progresso econômico nacional.

Chermont de Brito, em coluna assinada no dia 31 de agosto de 1960, afirmou que "o erro do Brasil [...] foi lançar-se desordenadamente à industrialização, sem procurar atender às questões do desenvolvimento agrícola, fundamentais para se assegurar condições propícias à industrialização" (BRITO, 1960, p. 3). Desse modo, se fazia necessária uma política que orientasse o produtor e facilitasse a liberação de recursos financeiros para modernização e mecanização das lavouras. Segundo o Jornal do Brasil, o ponto ideal de um processo de desenvolvimento não era o da superação da agricultora pela indústria, mas o equilíbrio entra as duas alas.

A linha editorial adotada por última Hora, que durante todo o período eleitoral manteve apoio declarado à candidatura Lott, apresentou uma solução diferente. Seus editoriais também afirmavam que "ao progresso de alguns setores contrapõe-se, numa contradição gritante o atraso de muitos outros. 0 país se desenvolve com ímpeto irresistível, talvez por isso mesmo desordenadamente". Contudo, esse era um problema internacional enfrentado por todos os países subdesenvolvidos, inseridos na luta pela emancipação nacional. A continuação do embate e a superação das dificuldades dependeriam da continuidade de um projeto de governo que promovera tão rápido avanço do Brasil nos últimos anos, alçando o país à situação de "única nação deste hemisfério que já possui condições para pesar nas decisões internacionais" (Às URNAS..., 1960, p. 1).

Em seus editoriais, a Tribuna da Imprensa defendeu o desenvolvimento econômico por meio de uma política industrial de caráter privado e da descentralização administrativa. Diante da incapacidade de gestão do Estado, as escolas também deveriam ser entregues à iniciativa privada. Essa visão era a marca de uma concepção liberal de baixa intervenção estatal nos rumos da economia. Segundo a opinião da Tribuna da Imprensa, a política desenvolvimentista deveria estar em "estreita colaboração" com países que defendiam a liberdade do mundo "contra a avalanche comunista". Despindo-se assim, dos "preconceitos obscurantistas que constituíam um dos fatores 
auxiliares da ofensiva soviética sobre nosso continente". Declarando-se em favor da candidatura de Jânio Quadros, o jornal classificou os partidários da chapa Lott - Jango de "falsos nacionalistas" e "verdadeiros entreguistas", pois não havia nada mais antinacional do que a política econômica adotada pelo governo de Juscelino Kubitschek. O projeto que novamente recebia o apoio da "chapa governista" aviltara e degradara a moeda nacional.

Por sua vez, os editoriais do Jornal do Brasil destacavam que o desenvolvimento permitiu que a nação brasileira se afirmasse soberanamente. 0 país havia perdido o complexo de inferioridade e conseguido se projetar ao estrangeiro. Um ambiente de paz interna e de continuidade política condizia com o de uma nação verdadeiramente livre. A partir da articulação entre os editoriais e os projetos defendidos pelos candidatos, percebe-se que um discurso em favor das chamadas vantagens comparativas e da "vocação agrária" nacional fora abandonado em direção à defesa de um desenvolvimento industrial com algum grau de apoio estatal (GUIMARÃES, 2001, p. 167). A contumaz crítica a qualquer participação de Estado, presente nas páginas da Tribuna da Imprensa não seriam plenamente incorporados por Jânio Quadros e o debate acerca da produção agrícola então passava a se orientar para uma discussão entre mecanização e reforma agrária, que ganharia ainda mais impulso nos anos seguintes.

O debate acerca da diminuição das desigualdades e da superação do atraso de determinados setores, estabelecia um diálogo entre o desenvolvimento econômico, as bases do regime democrático e as transformações vivenciadas pelas camadas populares. Não por acaso, ao analisar os rumos da democracia no Brasil nos últimos anos, o Jornal do Brasil sinalizou que a cada vez que se exercitava o voto, estabelecia-se ainda mais a consciência dos fatores básicos que configuravam a própria nação: "sua unidade, seu desenvolvimento econômico, seu ímpeto de progresso, sua ânsia de se educar e de civilizar-se, sua urgente necessidade de livrar-se da humilhação e da miséria forçada" (O PODER..., 1960, p.3).

Para o jornal, nesse momento, a política de emancipação nacional estava diretamente ligada à entrada de um contingente eleitoral mais expressivo no processo político. A cada eleição realizada se revelava a consciência cidadã e o 
amadurecimento do "povo inteiro". Se, em eleições anteriores, diversos jornais se preocuparam em distinguir o povo, enquanto conjunto de cidadãos conscientes, das massas deseducadas e amorfas, no pleito de 1960 a situação se modificou. Em coluna assinada do dia 22 de setembro de 1960, intitulada Cabeça e coração, Tristão de Athayde destacou que:

se houve alguma coisa de positivo na vitória da Revolução de 30, foi precisamente alargar a participação do povo no processo eleitoral. E quando digo povo, incluo massas e elites [...] um dos ideais do regime democrático é precisamente integrar elites e massas, na mesma resultante: Povo, Massas e Elites, sociologicamente falando, são conceitos relativos e subordinados a essa entidade superior, o Povo, que é o corpo da nacionalidade. (ATHAYDE, 1960, p. 3)

Direcionado aos "católicos", o texto do colunista destacou o valor do voto consciente e a responsabilidade de seu exercício. Embora os partidos políticos se encontrassem mutilados, o povo não fora jogado à marginalização. Para além das paixões partidárias, o voto deveria ser praticado com a mente fria e o coração quente. O povo passava a ser qualificado enquanto o corpo na nação.

A valorização da participação popular no pleito esteve muito presente nos discursos de campanha dos candidatos. Se, por um lado, Lott e os petebistas acreditavam na "conscientização" do povo através da ideologia do nacionalismo desenvolvimentista, por outro, o pensamento udenista defendia que o amadurecimento cívico estava vinculado à necessidade de renovação da República brasileira, corrompida política e financeiramente por demagogos. As campanhas disputaram a simpatia de um eleitorado que aumentara expressivamente nos últimos anos 23 . A "maioridade" do eleitorado nacional ganhou destaque em discursos que, ao longo dos anos 1950, por vezes foram antagônicos. No dia seguinte ao pleito, a Coluna de Última Hora publicou:

\footnotetext{
${ }^{23}$ Com relação a esse aumento acelerado, ressalta-se que desde a proclamação da República até o fim do Estado Novo, a participação política eleitoral no Brasil nunca ultrapassara 5\% do total da população. Após 1946, o percentual subiu para algo entre 15 e 20\% tendo seu percentual mais alto nas eleições presidenciais de 1960 em 12.5 milhões de eleitores participaram do pleito. Ainda assim, também é importante ressalvar os limites dessa democracia "em tempos de Guerra fria”, que além de manter os comunistas alijados do cenário político-partidário, ainda convivia com resquícios autoritários que excluíam do processo eleitoral a enorme gama de analfabetos, então 40\% da população maior de 15 anos, considerados incapazes para o exercício do voto (REZNIK, 2004, p. 19).
} 
Sejam quais forem os obstáculos a vencer, o povo brasileiro avança no caminho da democracia, demonstrando que pode conseguir, com seu voto esclarecido, com sua consciência cívica, os instrumentos políticos necessários para levar a cabo o processo de emancipação nacional que caracteriza a presente fase de nossa evolução histórica. (MAIS..., 1960, p.3.)

O ambiente de valorização da participação do povo na política também foi reverberado pelo Jornal do Brasil. Em editorial, o jornal sustentou que após alguns anos de exercício livre, democrático e absolutamente necessário do voto, o clima de normalidade eleitoral então vivenciado comprovava os avanços de "nossa redemocratização política”, e demonstrava que

a democracia brasileira, na sua característica mais expressiva, que é a escolha periódica dos dirigentes da Nação através do voto livre e secreto, já não se encontra mais em fase experimental: 15 anos do exercício do sistema representativo em todos os níveis de governo, demonstram com segurança que o nosso roteiro se consolida proveitosa e animadoramente. (O VOTO..., 1960, p.3)

\section{Considerações finais}

Ao longo das três campanhas presidenciais analisadas, entre 1950 e 1960, as páginas dos jornais pesquisados apontam para a consolidação do conceito de povo enquanto o conjunto de eleitores aptos ao exercício democrático. Pode-se dizer, além disso, da compreensão por parte dos atores políticos da inevitabilidade dessa presença e desse exercício, por parte do conjunto da população recém-incorporada ao sistema eleitoral. Aos poucos, ficara evidente que, para sagrarem-se vitoriosas, as campanhas eleitorais para a presidência dependeriam do sucesso de um processo de incorporação de valores e demandas do campo popular.

Forma-se uma linguagem política na qual essas demandas e valores deveriam se associar a distintas compreensões da noção de povo e de suas “famílias" conceituais. É perceptível, portanto, duas compreensões sobre a maturidade dos eleitores: uma narrativa que a vinculava ao exercício periódico do pleito e outra que a relacionava a sua politização dentro de um projeto político ideológico específico. Entretanto, o impedimento à participação dos analfabetos 
e do partido comunista, vigentes em 1960, não representava constrangimento à avaliação feita de que a democracia estava consolidada, do ponto de vista do sistema eleitoral vigente e da ampliação do sufrágio. Essa situação não deixa de evidenciar certa continuidade das tensões interpretativas entre as noções de massa, povo, eleitor e cidadão e, assim, indicar limites para o jogo democrático e seus participantes admissíveis.

O conceito de desenvolvimento econômico consolidou-se na linguagem política brasileira, já na corrida presidencial de 1955, enquanto a modernização das estruturas industriais, fossem elas no campo ou no meio urbano, o crescimento do consumo interno a partir de investimentos estatais ou privados, nacionais ou estrangeiros. Durante o governo de Juscelino Kubitscheck, o desenvolvimentismo ganharia força como a ideologia do crescimento econômico e industrial vinculado a um projeto urbano de modernização das estruturas econômicas. Tanto democracia quanto o desenvolvimento, chegado o ano de 1960, estiveram associados ao vocabulário político do liberalismo ${ }^{24}$. Democracia representativa vista como exercício eleitoral, com ênfase na harmonia e na paz social, afastada do campo identificado no contexto de Guerra-Fria ao bloco oriental e ao comunismo. O desenvolvimento passa a ser compreendido como o aumento da industrialização e do crescimento econômico amparados na oferta de serviços e bens de consumo com ênfase no setor privado.

Ao longo dos anos 60, em especial, no governo de João Goulart, a "linguagem do desenvolvimento" se colocará sob uma retórica da universalização da justiça social, não podendo negligenciar o eleitorado empobrecido das cidades ou do campo. As pressões em favor da adoção de uma política de desenvolvimento de cunho nacionalista estiveram na base da ação da Frente Parlamentar Nacionalista e da Frente de Mobilização Popular, articulada ao final de 1962. Ainda que o setor agrário continuasse gozando de prestígio e poder nas decisões políticas, muitos foram os ataques de atores político sociais como as

\footnotetext{
${ }^{24}$ Vale ressaltar que, ao longo desse período, com algumas idas e vindas, esses conceitos também foram interpretados sob a ótica comunista, cujas ideias foram reverberadas por periódicos como a Imprensa Popular e o semanário Novos Rumos (MIRANDA, 2014). Contudo, a própria ilegalidade do Partido Comunista, proscrito da cena político-partidária em 1947, aponta para a hegemonia do discurso liberal.
} 
Ligas Camponesas, a União dos Lavradores e Trabalhados Agrícolas ou dos sindicatos rurais, em franco crescimento no período ${ }^{25}$.

Naquele momento, demandas pela regularização dos direitos trabalhistas do campo, pela Reforma Agrária e em favor da extensão do voto aos analfabetos seriam colocadas sob a perspectiva da ampliação da presença da população nos rumos econômicos e políticos do país. Assim, o conceito de desenvolvimento presente no jogo político da década de 1960 não comportaria uma retórica agrária e ruralista que não levasse em conta a crescente participação do povo nos rumos nacionais, tal como salientou Alberto Guerreiro Ramos (1961) em texto apontado na epígrafe deste artigo. As demandas por direitos básicos da cidadania, negligenciadas na era JK, implicariam em uma remodelação do debate político no que tange à "linguagem do desenvolvimento".

Por outro lado, aspecto marcante das transformações das linguagens políticas da década de 1950 é sua reatividade ao projeto político ideológico do trabalhismo e do legado de Getúlio Vargas. Antes de 1954, povo era todo cidadão que votaria "corretamente" contra o ditador e "demagogo", Vargas, e as massas, aquele contingente recém-chegado do jogo eleitoral suscetível ao projeto trabalhista caracterizado muitas vezes, à época, enquanto um projeto populista. Nesse sentido, a retórica elitista representou uma forte influência nesse contexto linguístico. Após a morte de Getúlio Vargas, entretanto, os cidadãos seriam aqueles que participavam do jogo democrático e cujo voto seria disputado pelos candidatos à presidência. O que se percebe, portanto, é a paulatina construção da noção de democracia como o regime político no qual as decisões do povo seriam conhecidas através do voto. Limitada por marcos liberais próprios do contexto linguístico brasileiro, a democracia se consolidará na década de 1960 enquanto um sistema representativo e quaisquer tentativas de ampliação da participação para além do jogo eleitoral seriam atacadas.

\footnotetext{
${ }^{25}$ No ato de criação da Confederação Nacional dos Trabalhadores na Agricultura (CONTAG) no final de 1963, já se registravam 743 sindicatos rurais em contraposição aos cinco então reconhecidos no ano de 1960. Isso evidenciava que a pressão organizada dos trabalhadores em prol da reforma agrária se ampliava. Em março daquele ano, sua ação contribuíra para que finalmente fosse aprovado o Estatuto do Trabalhador Rural, que basicamente estendia a legislação trabalhista para o campo (GRYNSZPAN, 2006, p. 64-68).
} 
Ainda no pleito de 1960, a articulação entre exaltação da "consciência" do povo brasileiro e a "consolidação da democracia" nacional, particularmente destacadas nos editoriais do Jornal do Brasil e Última Hora, pareciam apontar para um futuro promissor. Naquele momento, os esforços para desqualificar ou ignorar o novo eleitorado converteram-se em tentativas mais nítidas de negociação para a definição dos rumos políticos nacionais. Constituiu-se, assim, em um período de inflexão, no qual, os mais distintos atores políticos incorporaram a seus discursos uma crescente valorização do papel do povo, como a totalidade dos eleitores, no regime democrático. Ainda assim, o aumento da presença na cena política de grupos mais permeáveis às demandas populares se associou aos limites impostos ao imaginário discursivo dos grupos mais à direita do espectro político, possibilitando um novo ímpeto a análises desqualificadoras da ação do povo na política.

Nunca é demais lembrar que essa mesma democracia seria derrubada poucos anos depois em um contexto marcado por demandas de participação política por setores sociais tradicionalmente alijados do processo eleitoral. Nesse cenário, por sua vez, em lugar da desqualificação do voto dos eleitores de Jango, ganharia impulso o argumento acerca da impossibilidade - e da ilegalidade - de participação política fora do pleito eleitoral, conferindo a prerrogativa de decisão política aos representantes eleitos. Aos poucos, essas interpretações alimentaram vozes que sustentavam a necessidade de "proteção" e "condução" do povo frente a perigos e desvios 'incompreendidos', que dentre outros fatores, se uniriam a um conjunto de supostas justificativas para a afirmação do regime ditatorial no Brasil (MIRANDA, 2014, p. 20).

Em março de 1964, momentos antes do golpe que pôs fim a primeira experiência democrática de massas no Brasil, ao avaliarem as mobilizações do Comício da Central do Brasil e da Marcha com Deus pela Liberdade, alguns jornais retomam argumentos que distinguiam a 'massa passional' de 'cidadãos sensatos' nos eventos (MATTOS, 2019, p. 184). Se nas eleições de 1950 e 1955, os argumentos mobilizados relacionavam-se à falta ou posse da consciência no ato do voto, agora, contra Jango e seu governo legalmente eleitos, o que estava em jogo era a impossibilidade de pressionar o Congresso fora do pleito. 
Manifestações de militares de baixa patente, greves, mobilizações interpretadas como "radicais" ou comunistas, na cidade ou no campo, foram lidas, não apenas como irracionais, mas ilegais. E assim o foram caracterizadas pelos jornais à época, por estarem fora dos limites estabelecidos nas linguagens políticas que se transformavam desde 1950.

Nos anos anteriores ao desfecho autoritário, a defesa de uma democracia liberal representativa, na qual o povo deveria exercer seus direitos políticos através apenas do voto, foi largamente propalada pelos jornais analisados. Do ponto de vista da importância do estudo das linguagens políticas, a década de 1950 permite que se compreenda de que forma os atos de fala em defesa da democracia foram mobilizados para sustentar o golpe e, defender, deste modo, a salvaguarda da legalidade e da democracia.

\section{Referências}

ABREU, Alzira Alves de; BELOCH, Isabel; LATTMAN-WELTMAN, Fernando e LAMARÃO, Sérgio Tadeu de Niemeyer (coord.). Dicionário histórico-biográfico brasileiro pós 1930. Rio de Janeiro: Ed. FGV/CPDOC, 2001.

ABREU, Alzira Alves; LATTMAN-WELTMAN, Fernando; FERREIRA, Marieta de Moraes e RAMOS, Plínio de Abreu (org.). A imprensa em transição: o jornalismo brasileiro nos anos 50. Rio de Janeiro: editora FGV, 1996.

A LEGALIDADE e o contragolpe. Tribuna da Imprensa, Rio de Janeiro, ano VII, p. 4, 02 ago. 1955.

A NOVA proclamação da República. Tribuna da Imprensa, Rio de Janeiro, ano VII, p, 4, 20-21 ago. 1955.

ÀS URNAS pelo Brasil. Última Hora, Rio de Janeiro, edição Estado do Rio de Janeiro, ano X, n. 3151, p.1, 03 out. 1960.

ATA contra elites. Correio da Manhã, Rio de Janeiro, ano LX, n. 20696, 13 set. 1960. Tópicos \& notícias, p. 6. 
ATHAYDE, Tristão de. Cabeça e coração. Jornal do Brasil, Rio de Janeiro, ano LXX, n.223, p. 3, 22 set. 1960

BARBOSA, Leonardo Martins. Crise e transição na Revista Cultura e Política (1978-1982): uma análise do momento da abertura. 2010. Dissertação (Mestrado em História) - Pontifícia Universidade Católica do Rio de Janeiro, Rio de Janeiro, 2010.

BARBOSA, Marialva. História cultural da imprensa: Brasil, 1900-2000. Rio de Janeiro: Mauad X, 2007

BENEVIDES, Maria Vitória de Mesquita. O governo Jânio Quadros. São Paulo: Brasiliense, 1981.

BENEVIDES, Maria Victoria. O governo Kubitschek: a esperança como fator de desenvolvimento. In: GOMES, Ângela Maria de Castro. O Brasil de JK. Rio de Janeiro: Editora da FGV/CPDOC, 1991. p. 9-22.

BEVIR, Mark. The Contextual Approach. In: KLOSKO, George. The Oxford handbook of the history of political philosophy. 1. ed. Oxford: Oxford University Press, 2011. p. 11-24.

BIELSCHOWSKY, Ricardo. Pensamento econômico brasileiro: o ciclo ideológico do desenvolvimentismo. Rio de Janeiro: IPEA/INPES, 1988

BETHELL, Leslie. Brasil. In: BETHELL, Leslie; ROXBOROUGH, Ian. Entre a Segunda Guerra Mundial e a Guerra Fria. Rio de Janeiro: Paz e Terra, 1996. p. 65-112.

BOTELHO, André; SCHWARCZ, Lilian. Simpósio: cinco questões sobre o pensamento social brasileiro. Lua Nova: Revista de Cultura e Política, São Paulo, n. 82, p. 139-159, 2011.

BRITO, Chermont. Agricultura e industrialização. Jornal do Brasil, Rio de Janeiro, ano LXX, n.204, p. 3, 30 ago. 1960.

CHALOUB, Jorge Gomes de Souza. O Brasil dos bacharéis: um discurso liberal udenista. Lua Nova: Revista de Cultura e Política, São Paulo, n. 107, p. 263-304, 2019.

COERÊNCIA de sr. Lafer. Correio da Manhã, Rio de Janeiro, ano LX, n. 20682, 27 ago. 1960. Tópicos \& notícias, p. 6.

DEMOCRACIA sem instrumentos. Jornal do Brasil, Rio de Janeiro, ano LXX, n.195, p. 3, 19 ago. 1960 
FEBVRE, Lucien. Honra e pátria. Rio de Janeiro: Civilização Brasileira, 1998.

FERNANDES, Florestan. A revolução burguesa no Brasil: ensaio de interpretação sociológica. São Paulo: Globo Livros, 2006.

FERREIRA, Jorge. O populismo e sua história: debate e crítica. Rio de Janeiro: Civilização Brasileira, 2001.

FURTADO, Celso Furtado. A fantasia organizada. Rio de Janeiro: Paz e Terra, 1985.

GOMES, Ângela Maria de Castro. A invenção do trabalhismo. São Paulo: Vértice, Editora Revista dos Tribunais; Rio de Janeiro: IUPERJ, 1988.

GOMES, Ângela Maria de Castro. Introdução. In: GOMES, Ângela Maria de Castro. O Brasil de JK. Rio de Janeiro: Editora da FGV/CPDOC, 1991. p. 1-8.

GOMES, Ângela Castro. O populismo e as ciências sociais no Brasil: notas sobre a trajetória de um conceito. In: FERREIRA, Jorge (org.). O populismo e sua história: debate e crítica. Rio de Janeiro: Civilização Brasileira, 2001. p. 17-57.

GRYNSZPAN, Mário. O período Jango e a questão agrária: luta política e afirmação de novos atores. In: FERREIRA, Marieta de Moraes. João Goulart; entre a memória e a história. Rio de Janeiro: FGV, 2006 p. 57-77.

GUIMARÃES, César. Vargas e Kubitschek: a longa distância entre a Petrobras e Brasília. In: CARVALHO, Maria Alice Rezende. (org.). República no Catete. Rio de Janeiro: Museu da República, 2001. p. 155-175.

HOROWITZ, David. A aliança para o progresso. In: PEREIRA, Luiz (org.).

Perspectivas do capitalismo moderno. Rio de Janeiro: Zahar, 1971. p. 237-266.

IDENTIDADE com os problemas. Correio da Manhã, Rio de Janeiro, ano L, $\mathrm{n}$. 17616, p.1, 19 ago. 1950.

JAGUARIBE, Helio. O nacionalismo na atualidade brasileira. Rio de Janeiro: ISEB/MEC, 1958.

JAGUARIBE, Helio. Que é o Ademarismo? In: CADERNOS DO NOSSO TEMPO. Rio de Janeiro: IBESP, n. 2, jan.-jun. 1954, p. 23-30. 
JÂNIO é o terremoto cívico que cairá sobre esta Nação. Correio da Manhã, Rio de Janeiro, ano LX, n. 20678, p.16, 23 ago. 1960.

JASMIN, Marcelo Gantus; FERES JUNIOR, João. Uma história dos conceitos: debates e perspectivas. Rio de Janeiro: PUC-RIO: Edições Loyola: IUPERJ, 2006.

KOSELLECK, Reinhart. Futuro passado: contribuição à semântica dos tempos históricos. Rio de Janeiro: Contraponto: Ed. PUC-Rio, 2006.

LACERDA, Carlos. Editorial. Tribuna da Imprensa, Rio de Janeiro, ano II, p.3, 01 ago. 1950.

LACERDA, Carlos. Editorial. Tribuna da Imprensa, Rio de Janeiro, ano XII, p. 3, 23 ago. 1960.

LAVAREDA, Antônio. A democracia nas urnas: o processo partidário brasileiro. Rio de Janeiro: Rio Fundo Editora: IUPERJ, 1991.

LATTMAN-WELTMAN. A imprensa carioca nos anos 50: "os anos dourados". In: ABREU, Alzira et al. (org.). A imprensa em transição. Rio de Janeiro: FGV, 1996. p. $157-187$.

LIÇÕES da Argentina. Correio da Manhã, Rio de Janeiro, ano LV, n. 19153, p.6, 02 set. 1955.

LIMA, Hermes. Significação do Nacionalismo In: SCHWARTZMAN, Simon (org.). O pensamento nacionalista e os Cadernos do Nosso Tempo. Brasília: Editora UnB, 1988.

LOUREIRO, Felipe Pereira. Varrendo a democracia: Jânio Quadros e o Congresso Nacional. Revista Brasileira de História, São Paulo: ANPUH, v. 29, n. 57, p. 187208 jan-jun, 2009.

MAIS um grande passo no caminho da democracia. Última Hora, ano X, n. 3153, Rio de Janeiro, p.4, 04 out. 1960.

MARINGONI, Gilberto. Simonsen versus Gudin a controvérsia pioneira do desenvolvimento. Desafios do desenvolvimento, [Brasília], IPEA, ano 9, edição 73, 2012, p. 72-78.

MATTOS, Pablo de Oliveira. Para aonde vamos?: crise e democracia no governo João Goulart. Rio de Janeiro: Ed. Multifoco, 2019. 
MELO, Antônio Vieira de. O mal da multiplicidade dos partidos. A Noite, Rio de Janeiro, ano XXIX, n. 13581, p.3, 02 set. 1950.

MIRANDA, Mario Ângelo. Povo, democracia e legalidade nas linguagens políticas do Brasil (1945-1964) e do Chile (1939-1973) no contexto das experiências democráticas de massa. 2014. Tese (Doutorado em História) - Pontifícia Universidade Católica do Rio de Janeiro; Pontificia Universidad Catolica de Chile, Rio de Janeiro; Santiago de Chile, 2014.

MIRANDA, Mario Ângelo. A deposição de Juan Perón e sua repercussão no ambiente político das eleições presidenciais brasileiras de 1955. Revista Eletrônica Boletim do TEMPO, Rio de Janeiro, Ano 5, n.11, p. 1-6, 2010 a. Disponível em: www.tempopresente.org. Acesso em: 26 nov. 2013.

MIRANDA, Mario Ângelo. O Iseb seus intelectuais e a linguagem política dos anos 1950 no Brasil. Revista Eletrônica Boletim do TEMPO, Rio de Janeiro, Ano 5, n. 29, p. 1-7, 2010b. Disponível em: www.tempopresente.org. Acesso em: 25 nov. 2013.

MOREIRA, Vânia Maria Losada. Os anos JK: industrialização e modelo oligárquico de desenvolvimento. In: FERREIRA, Jorge; DELGADO, Lucília Neves de Almeida (org.). O Brasil republicano: o tempo da experiência democrática. Rio de Janeiro: Civilização brasileira, 2003. v. 3. p. 155-194

NICOLAU, Jairo Marconi. História do voto no Brasil. Rio de Janeiro: Jorge Zahar Editor, 2002.

NOSSA responsabilidade perante o mundo. Última Hora, [s.l.], ano V, n. B1138, Rio de Janeiro, p.4, 07 out. 1955.

O BRIGADEIRO e as populações rurais. Correio da Manhã, Rio de Janeiro, ano L, n. 17608, p.1, 10 ago. 1950.

O DRAMA da democracia. A Noite, Rio de Janeiro, ano XXIX, n.13610, p.3, 09 out. 1950. Ecos e novidades.

O NOSSO modo de ser a favor de Juarez. Tribuna da Imprensa, Rio de Janeiro, ano VII, p,3 22 set. 1955.

O PODER legítimo. Jornal do Brasil, Rio de Janeiro, ano LXX, n.233, p. 3, 04 out. 1960.

O PROGRAMA de Jânio. Jornal do Brasil, Rio de Janeiro, ano LXX, n.221, p. 3, 20 set. 1960. 
O QUE ele dirá... Correio da Manhã, Rio de Janeiro, ano L, n. 17610, p.1, 12 ago. 1950.

O VOTO responsável. Jornal do Brasil, Rio de Janeiro, ano LXX, n.214, p. 3, 11 set. 1960.

PELEGOS do sindicato do golpe não enganam mais... Última Hora, [s.l.], ano V, n. B1140, Rio de Janeiro, p.4, 10 out. 1955.

PLANO inclinado. Correio da Manhã, Rio de Janeiro, ano L, n. 17622, p.1, 26 ago. 1950.

POCOCK, John.Greville. Linguagens do ideário político. São Paulo: EDUSP, 2003.

PRÉLIO ordeiro. Correio da Manhã, Rio de Janeiro, ano LV, n. 19177, p. 6, 30 set. 1955.

RAMOS, Alberto Guerreiro. A crise de poder no Brasil. Rio de Janeiro: Zahar Editores, 1961.

REGAL, Débora Kfuri. Getúlio Vargas volta ao catete: a estratégia de propaganda varguista nas eleições de 1950. 2007. Dissertação (Mestrado em História) Pontifícia Universidade Católica do Rio de Janeiro, Rio de Janeiro, 2007.

REZNIK, Luís. Democracia e segurança nacional, a polícia política no Pós-Guerra. Rio de Janeiro: FGV, 2004.

RIBEIRO, Ana Paula Goulart. Jornalismo, literatura e política: a modernização da imprensa carioca nos anos 1950. Estudos Históricos, Rio de Janeiro, n. 31, p. 147-160, 2003.

SCHMIDT, Augusto Frederico. Definição. Correio da Manhã, Rio de Janeiro, ano LV, n. 19176, p. 2, 29 set. 1955a.

SCHMIDT, Augusto Frederico. O requerimento Falcão. Correio da Manhã, Rio de Janeiro, ano LV, n. 19172, p. 2, 24 set. 1955b.

SINAIS de incompreensão no campo da política nacionalista. Última Hora, [s.l.], ano V, n. 1292, Rio de Janeiro, p. 4, 06 set. 1955.

SKINNER, Quentin. The rise of, challenge to, and prospects for a Collingwoodian approach to the history of political thought. In: CASTIGLIONE, Dario.; 
HAMPSHIRE-MONK, lain. The history of political thought in national context. Cambridge: Cambridge University Press, 2001, p. 175-188.

SKINNER, Quentin. Meaning and understanding in the history of ideas. In: VISIONS OF POLITICS. United Kingdom: Cambridge University Press, 2002. v. 1.

SKINNER, Quentin. As fundações do pensamento político moderno. São Paulo: Cia das Letras, 2006

SODRÉ, Nelson Werneck. História da imprensa no Brasil. 4. ed. Rio de Janeiro: Mauad, 1999.

UM MÊS. Correio da Manhã, Rio de Janeiro, ano L, n. 17629, p. 1, 03 set. 1950.

VIANNA, Luiz Werneck. A revolução passiva: iberismo e americanismo no Brasil. Rio de Janeiro: Revan, 2004.

WEBER, Hilde. Carro-chefe. Tribuna da Imprensa, Rio de Janeiro, ano XII, p. 4, 26 ago. 1960.

WEFFORT, Francisco. O populismo na política brasileira. Rio de Janeiro: Paz e Terra, 1978. 